\title{
AVALIAÇÃO RADIOGRÁFICA DA REABSORÇÃO ÓSSEA PERIODONTAL POR MEIO DE VALOR DE PIXEL E COMPARAÇÃO COM ANÁLISE HISTOPATOLÓGICA
}

Ligia Buloto Schmitd

Dissertação apresentada à Faculdade de Odontologia de Bauru da Universidade de São Paulo como parte dos requisitos para obtenção do título de Mestre em Odontologia, área de Estomatologia.

BAURU

2005 


\section{AVALIAÇÃO RADIOGRÁFICA DA REABSORÇÃO ÓSSEA PERIODONTAL POR MEIO DE VALOR DE PIXEL E COMPARAÇÃO COM ANÁLISE HISTOPATOLÓGICA}

Ligia Buloto Schmitd

Dissertação apresentada à Faculdade de Odontologia de Bauru da Universidade de São Paulo como parte dos requisitos para obtenção do título de Mestre em Odontologia, área de Estomatologia.

Orientadora: Profa. Dra. Izabel Regina Fischer Rubira-Bullen

BAURU 
Schmitd, Ligia Buloto

Sc56a Avaliação radiográfica da reabsorção óssea periodontal por meio de valor de pixel e comparação com análise histopatológica / Liga Buoto Schmitd. - Bauru, 2005.

98p.: il.; $30 \mathrm{~cm}$

Dissertação (Mestrado) - Faculdade de Odontologia de Bauru, USP

Orientadora: Profa. Dra. Izabel Regina Fischer Rubira Bullen

Autorizo, exclusivamente para fins acadêmicos e científicos, a reprodução total ou parcial desta dissertação, por processos fotocopiadores e outros meios eletrônicos.

Assinatura:

Comissão de Ética no Ensino e Pesquisa com Animais da FOB

Protocolo $n^{\circ}$ 01/2004

Data: 04 de fevereiro de 2004. 
Ligia Buloto Schmitd

24 de setembro de 1979

Cachoeiro de Itapemirim - ES

Nascimento

$1997-2000$

Curso de Odontologia Faculdade de Odontologia de Bauru, USP

Curso de Aprimoramento em Câncer Bucal no Centro de

$2001-2003$ Tratamento e Pesquisa Hospital do Câncer A. C. Camargo, São Paulo, SP

$2003-2005$

Mestrado em Estomatologia na Faculdade de Odontologia de Bauru, USP

Sociedade Brasileira de Estomatologia - SOBE Associações

Sociedade Brasileira de Pesquisa Odontológica SBPqO

Associação Paulista de Cirurgiões-Dentistas - APCD 


\section{Dedicatória}

Ao meu pai e à minha mãe

Dedico esta dissertação às pessoas

que me ensinaram, com seus exemplos,

o valor do trabalho. 
"Sinto-me nascido a cada momento para a eterna novidade do mundo..." 'Porque conhecer é como nunca ter visto pela primeira vez, E nunca ter visto pela primeira vez é só ter ouvido contar"

'Porque eu sou do tamanho do que vejo E não do tamanho da minha altura ... ...porque a nossa única riqueza é ver." (Alberto Caeiro - heterônimo de Fernando Pessoa) 


\section{Agradecimentos}

$\mathcal{A}$ Deus, agradeço por ter saúde, e por ter sempre colocado pessoas maravifhosas em meu caminho.

Agradeço à minha família, pelo apoio incondicional. Ao meu pai e à minha mãe, por nunca dizerem não aos meus sonhos e por todo o investimento pessoal que fizeram durante os vários anos de distanciamento. Ao meu irmão, pelo exemplo e companheirismo.

Ao meu amor Rodrigo, por ser essa pessoa especial, a quem confio minha vida e com quem compartilho minhas angústias, meus anseios e os momentos mais felizes de uma vida que passarei ao seu lado.

Aos amigos Ana Raquel Benetti, Carla Ruffeil Moreira, Angélica Hannas, pela ajuda sem questionamentos, pela compreensão nos momentos difíceis.

À minha orientadora, por me incentivar e ensinar, na vida acadêmica e na vida pessoal. Por confiar e apoiar minhas idéias desde o nosso primeiro contato.

Aos amigos que estão distantes, em especial ao Felipe Ladeira Pereira, pela amizade incondicional e ao Ricardo $\mathcal{H}$. Suzuki, por ter sido amigo e "professor".

Aos meus colegas de Pós-graduação. A todos eles, pelo companheirismo no trabalho e também pelos momentos de descontração e boa convivência. Em especial, à Carla, à Etiene, ao Renato, ao Augusto, à Ana Raquel, ao Adilson, à Angélica, à Cássia, ao Marcelo Zanda, à Márcia, pela participação direta e indireta neste trabalho. 
À Camila de Oliveira Rodini, pela ajuda incomensurável na metodologia deste trabalho. Sua prestatividade e desprendimento em ensinar o que batalhou para aprender sozinha demonstram a grande pessoa que você é. Obrigada.

Ao Professor Gerson Francisco de Assis pela valiosa orientação.

Aos professores do Departamento de Estomatologia. Dr José Humberto Damante. Dr Luiz Eduardo M. Chinellato, Dra Ana Lúcia A. Capelozza, Dr Osny Ferreira Júnior, Dr. Eduardo Sant'Ana, e a todos os outros que durante toda a minha vida contribuíram para minha formação com seus ensinamentos preciosos. Ao Marcos Martins Curi, pelos valiosos ensinamentos e amizade.

Ao Professor Roberto Pereira Lauris, pelo grande auxílio na estatística deste trabalho.

Aos funcionários do Departamento de Estomatologia: Marília Gião, Fernanda Aparecida Daniel Cavalari, Josieli Aparecida Tripodi Farinha, Roberto Ponce Salles, Camila Medina, aos mirins Tânia, David e Reinaldo, e a todos os outros funcionários da FOB, que, sempre tão prestativos e amigos, engrandecem nossos dias nesta casa.

À Daniele Santin Ceolin, à Tânia Mary Cestari e demais funcionários do Departamento de Histologia. A seriedade, competência e amizade destas pessoas faz do departamento de Histologia da FOB um lugar especial. Meu muito obrigado pelos momentos agradáveis de convivência.

Aos funcionários do Biotério da Faculdade de Odontologia de Bauru, pela cooperação e prestatividade.

À equipe do LAPIMO, da USP de São Carlos, em especial ao aluno de pós-graduação Maurício Escarpinati, por estar sempre disposto a ajudar e esclarecer. 


\section{SUMÁRIO}

\begin{tabular}{|c|c|}
\hline RESUMO...................... & $x$ \\
\hline 1 INTRODUÇÃO... & 1 \\
\hline 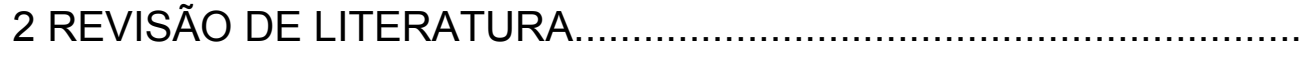 & 5 \\
\hline 2.1 Imagem digital.. & 6 \\
\hline 2.2 Radiografia digital - placa fotoestimulável (fósforo)....................... & 8 \\
\hline 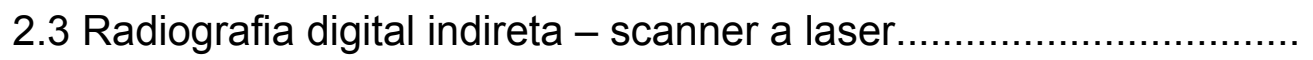 & 10 \\
\hline 2.4 A utilização do valor de pixel como ferramenta diagnóstica............. & 12 \\
\hline 2.5 Indução de doença periodontal em ratos.. & 22 \\
\hline 3 PROPOSIÇÃO .............................. & 26 \\
\hline 4 MATERIAL E MÉTODOS... & 28 \\
\hline 4.1 Grupos experimentais.................... & 29 \\
\hline 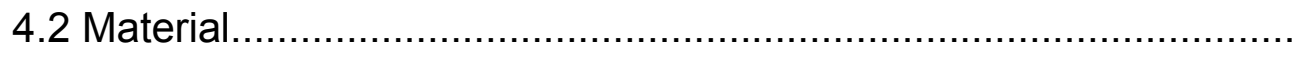 & 30 \\
\hline 4.3 Preparo dos animais / indução de doença periodontal.................... & 31 \\
\hline 4.4 Obtenção das peças cirúrgicas............ & 32 \\
\hline 4.5 Obtenção das imagens radiográficas.... & 34 \\
\hline 4.6 Procedimentos histotécnicos........ & 37 \\
\hline 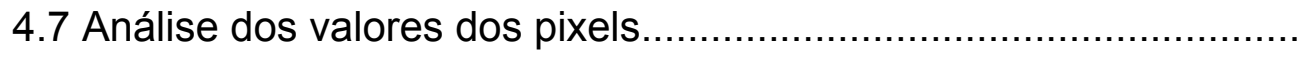 & 38 \\
\hline 4.8 Análise histopatológica.. & 41 \\
\hline 4.9 Análise estatística..................................... & 45 \\
\hline
\end{tabular}




\begin{tabular}{|c|c|}
\hline 5 RESULTADOS & 47 \\
\hline 5.1 Análise das imagens obtidas no sistema Digora........ & 50 \\
\hline 5.2 Análise das imagens digitais indiretas...... & 55 \\
\hline 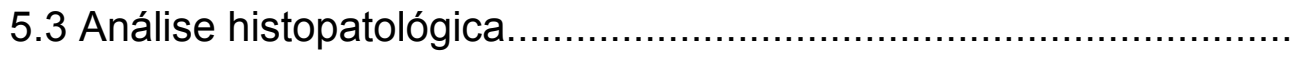 & 58 \\
\hline 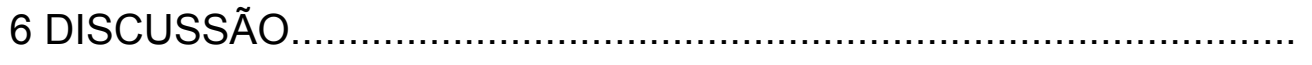 & 70 \\
\hline 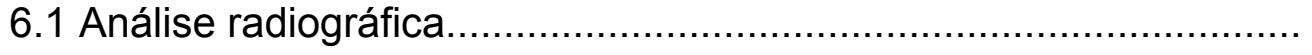 & 71 \\
\hline 6.2 Análise histopatológica................ & 78 \\
\hline 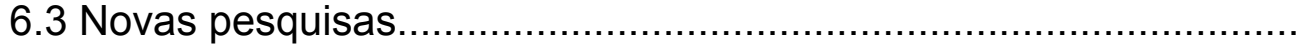 & 82 \\
\hline 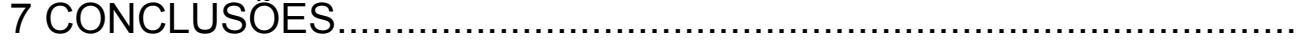 & 83 \\
\hline 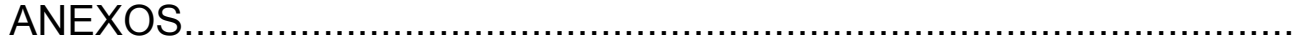 & 85 \\
\hline 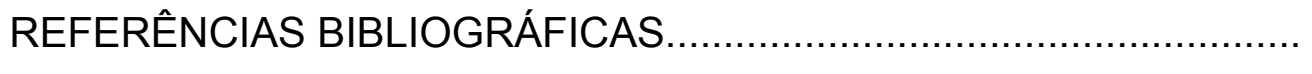 & 86 \\
\hline ABSTRACT & 98 \\
\hline
\end{tabular}




\section{RESUMO}

Avaliar radiograficamente a reabsorção óssea periodontal por meio do valor de pixel e sua comparação com o exame histopatológico foi o objetivo deste trabalho. Trinta ratos Wistar foram submetidos à indução de doença periodontal com fio de seda 3-0 ao redor do primeiro molar inferior direito e o lado esquerdo foi deixado como controle. O grupo 1 foi sacrificado após passados 7 dias, o grupo 2, após 14 dias e o grupo 3 após 28 dias. As hemimandíbulas dos 30 animais foram radiografadas em filmes radiográficos tamanho 2 e na placa fotoestimulável de fósforo do sistema Digora $\AA^{\text {. As }}$ radiografias convencionais foram digitalizadas em um scanner a laser. As peças foram processadas para cortes microscópicos e coradas em HE para análise. As médias dos valores dos pixels das áreas de doença e das áreas controle foram aferidos no programa Image $(\AA$. O teste ANOVA a dois critérios mostrou que os valores dos pixels das áreas de doença periodontal foram significantemente menores do ponto de vista estatístico, quando comparados às áreas de controle, tanto para as radiografias obtidas com o sistema Digora ${ }^{\circledR}$, quanto para as digitalizadas. No entanto, a ANOVA a um critério das médias dos valores dos pixels das áreas de doença periodontal não mostrou diferença estatisticamente significante entre os diferentes períodos experimentais. A análise microscópica evidenciou perda óssea, com aumento de osteoclastos e diminuição da altura da crista óssea alveolar com o passar do período experimental. Como conclusão, a análise do valor de pixel de uma radiografia digital foi capaz de evidenciar perda óssea quando comparada com seus controles, mas falhou ao detectar as alterações ósseas progressivas que foram visualizadas microscopicamente. 


$$
\text { Introdução }
$$




\section{INTRODUÇÃO}

A avaliação de pequenas alterações de mineralização no osso de suporte alveolar é importante para o diagnóstico precoce da doença periodontal, para o planejamento, direcionamento e acompanhamento das terapias empregadas. O método diagnóstico preconizado na prática periodontal seria a sondagem do sulco gengival com sonda milimetrada associada ao exame radiográfico. A radiografia é indispensável no exame periodontal, por fornecer informações essenciais sobre o tecido ósseo, que não pode ser avaliado de maneira clínica ${ }^{67}$.

Apesar de o exame radiográfico convencional ser a principal ferramenta para a avaliação da destruição óssea periodontal, ainda deixa a desejar por causa de sua baixa sensibilidade e alta discordância interexaminadores. ORTMAN, McHENRY, HAUSMANN ${ }^{53}$, em 1982, demonstraram que seria necessária uma perda óssea de 30 a $60 \%$ para que esta fosse detectada radiograficamente. Outros estudos demonstraram que a radiografia convencional seria incapaz de detectar perdas de osso 
medular. A destruição óssea só seria detectada quando a espessura da cortical ou ao menos a junção entre osso medular e cortical fosse afetada ${ }^{5,6,}$ 13,61

Um procedimento radiográfico ideal deveria proporcionar a coleta de informações quantitativas sobre uma alteração óssea. A obtenção de dados radiográficos objetivos torna-se ainda mais importante em periodontia, porque a progressão da doença periodontal é lenta e as diferenças de mineralização óssea visualizadas em duas radiografias subseqüentes poderiam ser muito sutis ${ }^{28}$.

Com os avanços na radiologia médica e odontológica, imagens puderam ser transformadas do formato analógico para o digital, permitindo uma gama enorme de ferramentas de manipulação e quantificação, armazenamento e transmissão digital de imagens. Esta evolução aproximou o exame radiográfico do que seria considerado ideal, no qual imagens podem ser manipuladas para melhorar a aparência, diminuindo a necessidade de repetições. Ainda, podem ser submetidas a operações matemáticas, como mensuração de distâncias lineares, de ângulos, cálculo de volume e determinação do valor de pixel, na tentativa de tornar objetiva a análise ${ }^{45,47}$.

A mensuração do valor de pixel em radiografias digitais poderia contribuir na detecção de alterações ósseas, mesmo que estas sejam bastante sutis. Os estudos clínicos sobre a avaliação dos valores de pixel são em sua maioria na área de endodontia, e as diferentes metodologias 
empregadas dificultam um parecer conclusivo sobre a utilização deste método na clínica diária. O assunto está ainda aberto para novas investigações, e há fortes indícios de que esta ferramenta de análise seja bastante útil na detecção radiográfica de alterações periapicais, mesmo nos casos de pulpites ${ }^{57}$.

Na doença periodontal, espera-se que ocorram pequenas mudanças ósseas na crista alveolar em períodos de acompanhamento curtos $^{29,44}$. Seria óbvia, portanto, a importância de se obter uma forma de avaliação bastante sensível em periodontia. A necessidade de meios diagnósticos cada vez mais acurados e sensíveis se faz presente pela constante busca por mecanismos preventivos ou curativos cada vez menos invasivos, no intuito de minimizar o impacto do tratamento empregado. 
Revisão de Literatura 


\section{REVISÃO DE LITERATURA}

\subsection{Imagem digital}

Enquanto a radiografia convencional é formada por um arranjo de cristais de prata sobre uma emulsão, a imagem digital é formada por pixels, que são os pontos da imagem. Cada pixel contém uma informação sobre a cor ou nível de cinza ao qual corresponde para formar a imagem ${ }^{3,21}$ (figura 2.1).

Os computadores trabalham com sistemas de dois dígitos, ou seja, sistema binário (binary digits $=$ bits), no qual os elementos gráficos são representados pelos algarismos 0 (zero) ou 1. Texto, imagem e som são escritos como elementos binários e cada pixel recebe uma determinada seqüência de zero e "1", correspondente à cor, intensidade do brilho ou luminescência do sinal captado. Em um sistema que trabalha com 8 bits, cada pixel corresponde a uma combinação de oito algarismos, chegando a 256 possíveis combinações de 0 e 1 . Essas 256 combinações, em uma imagem não colorida, correspondem a 256 níveis de cinza, onde zero seria o 
preto e 255 representaria o branco ${ }^{69,73}$. Em radiologia, então, zonas mais radiolúcidas teriam valor de pixel mais próximo de zero e zonas mais radiopacas estariam localizadas numa faixa mais próxima ao 255.
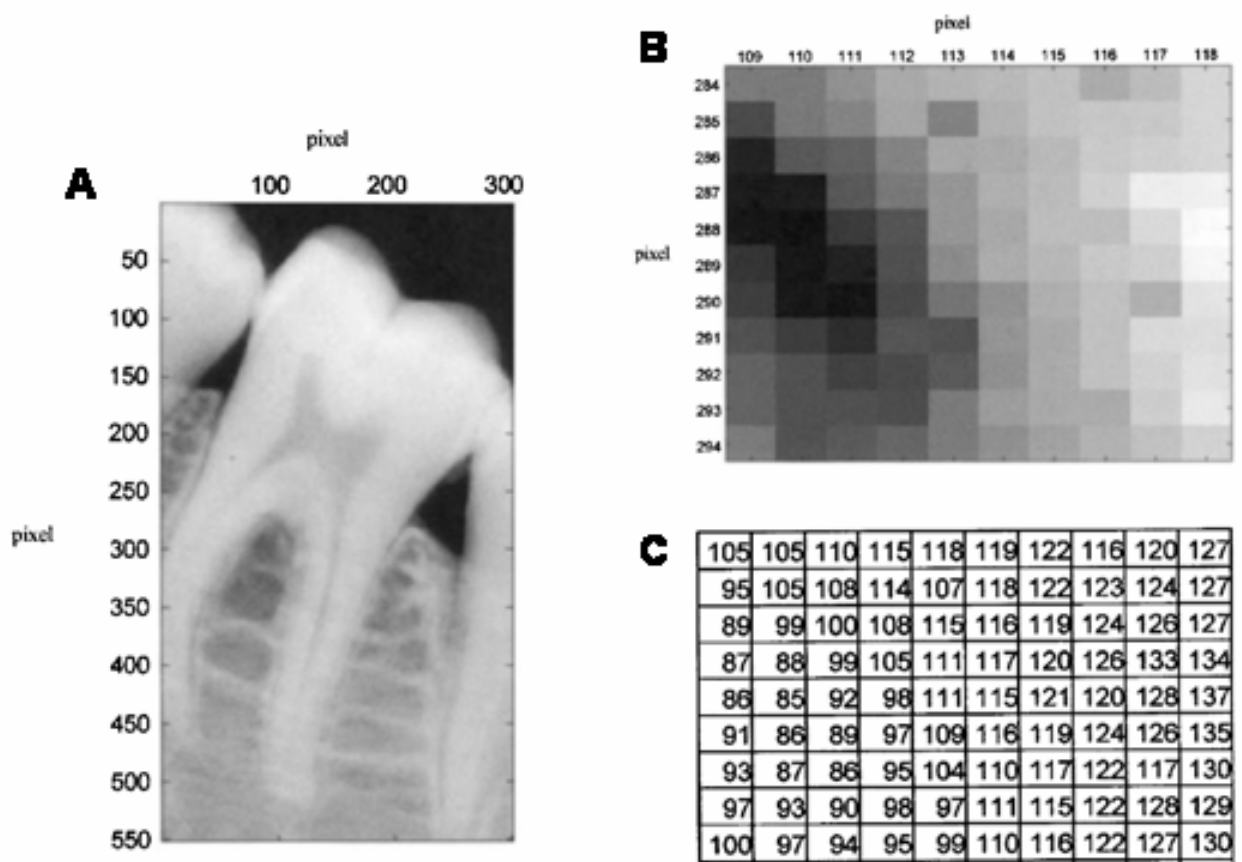

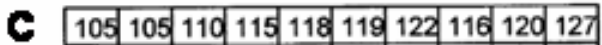

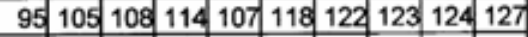
$8999100108 \quad 115 \quad 110 \quad 119 \quad 124 \quad 126 \quad 127$

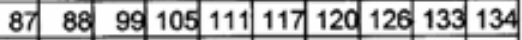
\begin{tabular}{llll|llllllll}
86 & 85 & 92 & 98 & 111 & 115 & 121 & 120 & 128 & 137
\end{tabular} \begin{tabular}{l|llllllllllll}
91 & 86 & 89 & 97 & 109 & 116 & 119 & 124 & 126 & 135 \\
\hline
\end{tabular} $\begin{array}{lllllllllllll}93 & 87 & 86 & 95 & 104 & 110 & 117 & 122 & 117 & 130\end{array}$ $\begin{array}{lllllllllllll}97 & 93 & 90 & 98 & 97 & 111 & 115 & 122 & 128 & 129\end{array}$ $\begin{array}{lllllllllllll}100 & 97 & 94 & 95 & 99 & 110 & 116 & 122 & 127 & 130\end{array}$ \begin{tabular}{llllllllll|l}
100 & 97 & 97 & 96 & 105 & 112 & 115 & 115 & 125 & 132 \\
\hline
\end{tabular} \begin{tabular}{lll|l|l|l|l|l|l|l|l|l|l|l|l|l|l|}
\hline 105 & 97 & 99 & 101 & 105 & 109 & 113 & 117 & 121 & 126 \\
\hline
\end{tabular}

FIGURA 2.1: A: Imagem radiográfica digital. B: Subseção da imagem A. C: Valores dos pixels correspondentes da imagem B. A imagem B foi ampliada para evidenciar as diferenças de tons de cinza entre os pixels (fonte: ANALOUI, M. $\left.{ }^{3}, 2001\right)$

Em sistemas de 12 bits, esse número de combinações de 0 e 1 sobe para 4096, representando uma maior variação de tons de cinza. Isso 
significa que o sistema consegue discriminar mais tons de cinza entre o preto e o branco. As imagens com finalidades odontológicas normalmente trabalham com 8 bits, mas as imagens de ressonância magnética são obtidas em sistemas de 12 bits $^{21,39}$.

\subsection{Radiografia digital - placa fotoestimulável de fósforo}

As placas fotoestimuláveis de fósforo estão disponíveis para aquisição de imagens radiográficas digitais diretas na radiologia médica há cerca de 2 décadas e foram originalmente desenvolvidas por Fuji Photo Film (Tokyo, Japan). Essas placas de fósforo são sensíveis à luz e funcionam como uma espécie de "filme reutilizável". Quando a placa é exposta, os fótons de energia da radiação $\mathrm{X}$ absorvida ficam armazenados em uma camada halogenada da placa, formando a imagem latente. Quando a placa é descarregada no sistema, ou seja, escaneada por um laser de hélio e neônio (He-Ne), os dados são emitidos em forma de luz. Essa luz é captada por sensores do scanner e convertida para o modo digital, então a informação é armazenada na forma digital $2^{21,30,69,70}$.

A placa é formada por uma base de poliéster impregnada por flúor, bário e európio ativado $\left(\mathrm{BaFBr}: \mathrm{Eu}^{2+}\right)$, revestida por halógenos cristalinos. Esses componentes são sensíveis à luz, e quando um fóton de radiação incide sobre eles, elétrons excitados são aprisionados na camada de cristais 
de fósforo, formando íons. Quando os cristais de fósforo são irradiados por uma segunda fonte, os elétrons aprisionados são liberados e recombinados. É a energia dessa recombinação que emite a luz que é posteriormente convertida para sinal elétrico ${ }^{35}$.

A placa de fósforo é sensível à luz visível e deve ser protegida até a sua leitura. Após a leitura, uma pequena quantidade de energia residual permanece depositada sobre a placa. Essa energia é removida pela exposição a uma luz halógena intensa, preparando a placa para uma nova exposição à radiação.

O primeiro sistema odontológico de radiografia digital direta utilizando placas de fósforo foi o Digora (Orion / Soredex, Helsinki, Finland), presente até hoje no mercado, com atualizações desde o seu lançamento ${ }^{66,74}$. Esse sistema possui placa de fósforo nos tamanhos $22 \times 31 \mathrm{~mm} ; 24$ × $40 \mathrm{~mm} ; 31$ x $40 \mathrm{~mm}$ e 27 x $54 \mathrm{~mm}$. Suas características de imagem e sua utilização clínica foram bem descritas na literatura ${ }^{66}$.

No sistema Digora mais atual, as imagens são armazenadas em 14 bits, com dói diferentes tamanhos de pixel disponíveis: 40 e $64 \mu m^{17}$. O tamanho do pixel das imagens obtidas na versão do Digora utilizada neste trabalho é de $70 \mu \mathrm{m}$ e a obtenção é de 8 bits ${ }^{4}$. Sua resolução espacial foi menor quando comparada aos sistemas digitais RVG-4®, CDR® e Dixel $\AA_{\text {, }}$ todos com captura por meio de CCD (Charge Coupled Device), por ARAKI, ENDO, OKANO ${ }^{4}$, em 2000. Neste mesmo estudo, o Digora demonstrou possuir a latitude mais ampla entre os 4 sistemas avaliados. 
Por causa da ampla latitude que as placas de fósforo apresentam, podem promover imagens de qualidade com uma grande variação de tempos de exposição ${ }^{30}$. Em imagens odontológicas não há necessidade de uma latitude muito grande e uma adaptação foi feita calibrando o sistema baseando-se na maior dose de radiação a ser utilizada. O objetivo da calibração é fazer com que as imagens obtidas no Digora tenham um equilíbrio na escala de cinza e brilho ${ }^{30,66}$.

A calibração deve ser realizada sempre antes da primeira tomada radiográfica, para adaptar o scanner ao nível de exposição, ajustando o seu mecanismo de leitura ${ }^{30}$. Além disso, o scanner deve estar calibrado para o nível de exposição mais alto a ser utilizado, permitindo uma exposição efetiva de $10 \%$ a $100 \%$ da exposição da calibração ${ }^{66}$. No entanto as doses muito baixas de radiação podem causar aumento de ruído, independente da dose utilizada na calibração ${ }^{30}$.

\subsection{Radiografia digital indireta - scanner a laser}

O uso dos scanners em radiologia odontológica tem crescido principalmente por ser uma opção de digitalização radiográfica de menor custo que os sistemas para radiografia digital direta.

Os scanners possuem uma fonte de luz em forma de linha que varre o objeto a ser digitalizado e mede a quantidade de luz refletida ou 
transmitida em cada ponto. A luz captada é convertida em um sinal elétrico e este sinal é posteriormente digitalizado ${ }^{20}$. Esses equipamentos podem utilizar basicamente três tecnologias de imagem: CCD (charge coupled device), PMT (tubos fotomultiplicadores) ou laser ${ }^{14}$.

HANGIANDEROU, O'CONNOR, FELMLEE ${ }^{27}$, em 1998, relataram que os scanners a laser sempre produziram imagens de melhor qualidade que os com CCD. DAVIDSON et al. ${ }^{14}$, no ano de 2001, avaliaram um scanner à laser (Lumisys 75), um scanner CCD e duas câmeras digitais em relação à qualidade da imagem original e da imagem corrigida por 10 radiologistas. As imagens obtidas pelos dois scanners foram preferidas pelos radiologistas. Analisando o contraste obtido pelos quatro equipamentos, o scanner a laser obteve a curva sensitométrica mais perfeita, mas forneceu valores maiores aos ideais nas regiões de maior densidade.

ESCARPINATI, VIEIRA, SCHIABEL ${ }^{20}$, em 2002, compararam a curva característica de filmes convencionais mamográficos em dois scanners a laser. Esses equipamentos calcularam o nível de cinza de cada ponto, multiplicando a sua densidade óptica por 1000. Para os dois scanners houve diferença em relação à curva ideal, e os autores propuseram um algorítimo de correção para calibração dos scanners.

OHKI, OKANO, NAKAMURA ${ }^{50}$, em 1994, relataram que o processo de digitalização seria muito importante para que não houvesse perda de informação nas densidades maiores, como a radiolucidez discreta das cáries proximais incipientes. Segundo FULTON ${ }^{22}$, a escolha da dpi a ser utilizada é 
o fator mais crítico no uso do scanner. Em um scanner com especificação de, por exemplo, $1200 \times 2400$ dpi, o menor número corresponde à resolução óptica. Uma resolução maior que a óptica pode ser obtida pelo scanner, porém esta será sempre interpolada, ou seja, feita pelo programa. A interpolação significa calcular valores que ocorrem entre dois valores conhecidos, acrescentando assim nova informação à imagem.

\subsection{A utilização do valor de pixel como ferramenta diagnóstica}

Alcance dinâmico (dynamic range) é o termo que define a quantidade possível de tons de cinza que um pixel poderia exibir ${ }^{59}$. O filme radiográfico convencional apresenta alcance dinâmico maior que o das radiografias digitais com aquisição em 8 bits, ou seja, maior que 256. No entanto, o olho humano tem uma capacidade pequena de distinção entre essas nuances de cinza.

O olho humano conseguiria discriminar cerca de 16 a 24 tons de cinza, segundo FARMAN, SCARFE ${ }^{21}$, em 1994. Portanto, as imagens obtidas em 8 ou 12 bits ultrapassam a capacidade de detecção visual humana.

Discute-se na literatura qual seria a utilidade de sistemas com alcance dinâmico que ultrapassa a capacidade visual humana. A obtenção de imagens com grande distinção de níveis de cinza poderia ser útil por três 
motivos: 1 - transformar as nuances de cinza em cores, pois o olho humano pode distinguir cerca de duas mil cores diferentes; 2 - mensurar tons de cinza, determinando um valor numérico que expresse, no caso de radiografias, perda ou ganho ósseo; 3 - realçar determinada faixa de tons de cinza em detrimento de outra (janelas) ${ }^{59}$.

A mensuração de tons de cinza seria mais sensível que a análise visual, pois no momento em que se determina a correspondência numérica dos pixels, diferenças mais sutis poderiam ser percebidas, antes mesmo que fossem perceptíveis aos olhos ${ }^{58,59}$. Na tentativa de validar essa hipótese, diferentes trabalhos foram realizados com diferentes metodologias, descritos nesta revisão.

No ano de 1990, ØRSTAVIK et al. ${ }^{51}$ avaliaram a eficácia de um sistema computadorizado de análise de imagem existente no mercado (Kontrom IBAS 2000®). Dentre outros fatores, avaliaram eficácia na análise automatizada do valor de pixel na diferenciação entre áreas saudáveis e áreas de lesão periapical em radiografias de tratamentos endodônticos em humanos. Para tal, utilizaram digitalização de radiografias convencionais. As áreas de lesão periapical foram delimitadas e uma área de osso saudável de tamanho semelhante ao redor de cada lesão foi igualmente marcada. Os resultados foram expressos pela razão entre as médias dos valores dos pixels das duas áreas. Nos casos em que houve cicatrização da lesão, houve aumento da razão, o que significou, segundo os autores, uma 
deposição de material mineral. De forma semelhante, as lesões que não tiveram melhora não mostraram mudanças nesta razão ao logo do tempo.

YOSHIURA, OHKI, YAMADA ${ }^{78}$, em 1991, analisaram sialografias de ratos portadores de sialoadenite na tentativa de avaliar a eficácia da medição do valor de pixel no diagnóstico da doença glandular. O histograma na escala de 8 bits foi obtido, com valores variando entre 0 e 255 para cada sialografia. Esses valores foram divididos em 5 faixas para análise: 0-15; 1631; 32-79; 80-127 e 128-255. Seus resultados justificaram a utilização futura do histograma como ferramenta diagnóstica em avaliação de sialoadenite, por encontrar diferenças de histograma entre glândulas saudáveis e doentes.

DUBREZ et al. ${ }^{18}$, em 1992, compararam a densidade óssea medida por dois métodos: fotodensitometria e análise do valor de pixel. Utilizaram radiografias padronizadas obtidas antes e depois de tratamentos periodontais em 8 pacientes. Após a fotodensitometria, as radiografias foram digitalizadas em um sistema de aquisição de 12 bits (4096 valores de pixel). Um penetrômetro de alumínio foi utilizado para correção do valor de pixel. Os autores concluíram que as duas técnicas são equivalentes na evidençiação de evolução de patologias periodontais.

A diferenciação entre cistos e granulomas pela análise do valor de pixel da imagem radiográfica foi proposta por SHROUT, HALL, HILDEBOLT $^{63}$, em 1993. Radiografias de arquivo de 10 lesões com diagnósticos histopatológicos de cistos e granulomas foram digitalizadas em 
um sistema de aquisição de 8 bits. As regiões de interesse foram demarcadas nas áreas de lesão, e os histogramas destas áreas foram analisados. Uma região de controle na área e dentina foi demarcada, para corrigir as diferenças de tempo de exposição e processamento radiográfico que ocorreram devido à não padronização das radiografias. Os resultados comprovaram a melhora na discriminação entre cistos e granulomas pelo histograma, e os autores sugerem que a análise por ferramentas digitais pode ser útil em diferenciar lesões que visualmente são indistinguíveis.

No ano seguinte, WHITE et al. ${ }^{75}$ encontraram ausência de diferenciação radiográfica entre cistos e granulomas, quando realizada análise do valor de pixel destas lesões. Num estudo semelhante ao de SHROUT, HALL, HILDEBOLT ${ }^{63}$, os autores coletaram 55 lesões periapicais, num total de 15 cistos e 40 granulomas com confirmação histopatológica. As radiografias foram digitalizadas em 8 bits e submetidas ao algorítimo de correção de RUTTIMANN, WEBBER, SCHMIDT ${ }^{56}$ para minimizar as diferenças de processamento radiográfico. O histograma das áreas de lesão foi obtido pelo software $\mathrm{NIH}$ Image ${ }^{\circledR}$. A mediana dos valores dos pixels foi utilizada para comparação e não houve diferença estatisticamente significativa entre os cistos e granulomas. Da mesma maneira, o valor de pixel não teve correlação com o tamanho das lesões.

Em 1997, KEROSUO, ØRSTAVIK ${ }^{38}$ avaliaram a reprodutibilidade da análise do valor de pixel em lesões periapicais, em comparação a um método visual, utilizando como padrão ouro o Índice Periapical ${ }^{52}$. Para tal, 62 
pacientes foram avaliados radiograficamente no começo do tratamento endodôntico e consecutivamente nos períodos experimentais de 1, 3, 6, 12 e 24 meses. A primeira radiografia da série foi utilizada para delimitar a lesão e uma área de osso normal ao redor da lesão, para comparação com as radiografias subseqüentes. A metodologia utilizada para avaliação do valor de pixel foi a mesma utilizada em estudo anterior de ØRSTAVIK et al. ${ }^{51}$. O método se mostrou reproduzível intra-examinador, mas a correlação interexaminadores variou de pobre a moderada. Para as lesões mais avançadas, a sensibilidade do método foi de $61 \%$ e a especificidade $79 \%$. No entanto, para as lesões menos severas, a especificidade foi menor, na ordem de $55 \%$. Os autores concluíram que o método de análise de imagem descrito parece ser uma ferramenta apropriada na detecção de alterações ósseas em radiografias odontológicas.

DELANO et al. ${ }^{15}$, em 1998, estudando métodos objetivos de avaliação radiográfica do tratamento de periapicopatias, induziram e trataram lesões periapicais em cachorros. Foram analisadas 33 raízes tratadas, comparando-se o aspecto inicial ao acompanhamento de 6 meses. As radiografias foram digitalizadas em 8 bits. As imagens obtidas foram submetidas à subtração radiográfica digital após a correção gama e analisadas por oito métodos de radiometria. Alguns destes métodos levaram em consideração a radiografia original, sem correção. $O$ padrão-ouro foi obtido pela morfometria dos tecidos após 6 meses. Dentre os métodos de radiometria por valor de pixel nas imagens originais, os autores avaliaram a mudança na razão entre as médias dos valores dos pixels de periapicopatias 
e regiões de osso normal, comparando o inicial e o controle de 6 meses $(\mathrm{CH}-\mathrm{R})$. Seus resultados mostraram que a $\mathrm{CH}-\mathrm{R}$ não se correlacionou positivamente com a morfometria, mas teve correlação com um dos índices (AP-SUB) obtidos pela subtração digital. A AP-SUB, por sua vez, teve correlação com a morfometria. Com base nestes resultados, os autores concluíram que a avaliação do valor de pixel em radiografias originais, sem métodos de correção pode ser um indicador de densidade eficaz e reproduzível, assim como as medidas de valor de pixel obtidas em imagens subtraídas que passaram por correção gama.

Um estudo realizado por SARMENTO, RUBIRA ${ }^{60}$, em 1998, avaliou 289 radiografias periapicais de arquivo, de dentes com diagnóstico clínico de pulpite, necrose ou considerados sadios. As radiografias foram digitalizadas pelo sistema DentScan DentView ${ }^{\circledR}$ e as médias dos valores dos pixels das regiões apicais foram medidas. Os resultados evidenciaram que os dentes normais apresentavam valores superiores quando comparados aos dentes com pulpite, e estes, por sua vez, apresentavam valores superiores aos dentes com necrose pulpar. Isso poderia ser explicado pelo fato de alterações teciduais já estarem presentes no tecido periapical antes da completa mortificação pulpar, e a ferramenta de análise ter sido capaz de captar essas alterações mesmo antes que a percepção visual pudesse detectá-las.

A diferenciação entre materiais restauradores resinosos pela medida de valor de pixel foi tentada por GÜRDAL, AKDENIZ ${ }^{26}$, em 1998. 
Radiografaram, na mesma película, discos construídos com 9 materiais resinosos diferentes, amálgama, tecido dentário humano cariado e hígido e um penetrômetro de alumínio. As radiografias foram digitalizadas em 8 bits e salvas no formato TIFF. As densidades ópticas dos materiais foram medidas nas radiografias convencionais e as médias dos valores dos pixels nas radiografias após digitalização. Os resultados evidenciaram maior eficácia do sistema digital em avaliar as diferentes radiopacidades dos materiais. A análise por valor de pixel melhorou a discriminação entre os materiais e a dentina, sugerindo que este método deva ser utilizado na prática clínica para diferenciação entre pequenas radiopacidades.

A qualidade da obturação do canal radicular por meio da análise do valor de pixel foi estudada por SARMENTO et al. ${ }^{58}$, em 1998. Sessenta caninos superiores foram obturados por três técnicas diferentes e radiografados no sistema Digora. As médias dos valores dos pixels dos materiais endodônticos foram mensuradas. Os resultados mostraram haver diferenças nos padrões dos valores dos pixels dos métodos de obturação estudados, avaliando assim a qualidade do tratamento endodôntico empregado.

Em 2000, SOUTHARD et al. ${ }^{64}$ estudaram a relação entre a densidade dos processos alveolares maxilar e mandibular e a densidade do esqueleto sistêmico. Realizaram radiografias periapicais de 41 mulheres com idades entre 20 e 78 anos e avaliação por densitometria óssea de seus esqueletos sistêmicos. As radiografias foram escaneadas em 8 bits e um algorítimo de 
correão de densidade baseado em um penetrômetro de alumínio foi utilizado para corrigir variações de exposição e processamento radiográfico. Esse algorítimo já havia sido previamente testado pelos próprios autores no ano anterior $^{65}$. As regiões de interesse foram demarcadas no osso alveolar e a densidade do local, baseada no valor de pixel do alumínio, foi aferida. Os autores encontraram correlação entre a densidade do osso alveolar e a densidade do esqueleto medida por densitometria óssea.

O valor de pixel periapical de molares de rato com pulpite e necrose pulpar foi avaliado por SARMENTO ${ }^{57}$ em 2000. Para confirmar o estado pulpar e avaliar a reabsorção de osso periapical, foi realizada análise microscópica. As mandíbulas de rato foram radiografadas no sistema digital direto Digora após 2 e 30 dias do procedimento de abertura pulpar no primeiro molar inferior direito dos animais. O grupo controle consistiu da análise do periápice de dentes sadios dos mesmos animais. As regiões de intesesse foram demarcadas no periápice dos dentes sadios e dentes testados e o valor de pixel foi solicitado no programa IP Tooth® (LISA, CPE, UCB, Lyon, França). Os resultados evidenciaram uma menor média e maior coeficiente de variação dos valores dos pixels apicais dos dentes com pulpite e com necrose pulpar quando comparados aos dentes sadios, indicando a possibilidade de detectar alterações ósseas precoces com o uso desta ferramenta de análise.

DELANO et al. ${ }^{16}$, no ano de 2001 , compararam um índice subjetivo (Índice periapica ${ }^{52}$ ) à densidade radiográfica por valor de pixel no 
acompanhamento de patologias periapicais tratadas em humanos. Foram feitas radiografias de 103 dentes antes do tratamento e após 1, 4, 12, 26 e 52 semanas. O índice periapical foi utilizado como padrão de comparação, e para tal, foi obtido por consenso entre 7 observadores calibrados. As radiografias foram digitalizadas em um sistema de aquisição de 8 bits. A avaliação de densidade periapical foi obtida pela razão entre as médias dos valores dos pixels das áreas de periapicopatias e de áreas normais de tamanho semelhante. Os resultados mostraram eficácia da medida de densidade por valor de pixel em evidenciar alterações ao longo do tempo, sendo semelhante aos resultados do índice periapical.

SHROUT et al. ${ }^{62}$, em 2003, investigaram a imagem radiográfica de osso medular através de quatro métodos de análise de imagem digital. Removeram gradativamente o osso medular de mandíbulas de cadáver e radiografaram as peças com um sistema digital direto $(C D R \otimes)$ de 8 bits. As regiões de interesse foram demarcadas nas imagens obtidas e a média dos valores dos pixels da região foi solicitada no software $\mathrm{NIH}$ Image ${ }^{\circledR}$. O uso do valor de pixel evidenciou mudanças significativas à medida que o osso medular foi removido, até mesmo para pequenas mudanças na quantidade de osso medular removido.

O mesmo grupo de autores publicou, em 2004, um trabalho bastante semelhante, com a mesma metodologia, porém, acrescentando uma análise visual das imagens. Observaram que as diferenças visuais nem sempre são 
aparentes, mas que os métodos digitais de medição evidenciaram as mudanças no conteúdo ósseo ${ }^{33}$.

CAMPS, POMMEL, BUKIET ${ }^{9}$, em 2004, compararam dois métodos de avaliação radiográfica de tratamento endodôntico em humanos: o índice periapical $^{52}$ e a medida do valor de pixel. Cinqüenta dentes com periapicopatias foram tratados e acompanhados por até 6 meses. As radiografias foram realizadas no início do tratamento e nos controles, sempre com penetrômetro de alumínio. Antes, os autores fizeram várias tomadas radiográficas do penetrômetro isoladamente, com tempos de exposição e condições de processamento diversas, para calcular o fator de correção que deveria ser utilizado no estudo in vivo. Para cada período de avaliação, foram avaliados o índice periapical e o valor de pixel das áreas de lesão, com a correção aplicada. Este estudo demonstrou que é possível evidenciar alterações ósseas em lesões periapicais pela medida de valor de pixel entre a radiografia inicial e seus controles, mesmo quando o índice periapical não sofre mudança.

Em periodontia, a imagem digital tem sido utilizada para acompanhamento de alterações ósseas por meio da subtração radiográfica digital (SRD) ${ }^{68}$. A SRD é uma possibilidade de manipulação digital, na qual duas imagens perfeitamente alinhadas obtidas com um intervalo de tempo são subtraídas matematicamente. Regiões onde não houvesse mudanças seriam eliminadas da imagem subtraída de forma a ressaltar visualmente as diferenças entre as imagens. Desta forma, pequenas mudanças nos tecidos 
seriam prontamente visualizadas nas imagens subtraídas. Além de ser expressa de forma visual (subjetiva ou qualitativa), a SRD pode ainda ser expressa de forma numérica (objetiva ou quantitativa). A SRD quantitativa expressa em unidades relativas aos valores dos pixels é denominada CADIA (Computed Assisted Densitometric Image Analysis - análise densitométrica assistida por computador) $)^{7,8,28,70}$.

No CADIA, a área ou região de interesse selecionada tem a média dos valores dos pixels medida e multiplicada pelo número de pixels da área onde ocorreu a mudança, na imagem subtraída, dando como resultado um valor numérico que pode ser positivo ou negativo. Valores negativos indicam diminuição de densidade óssea e valores positivos o aumento desta ${ }^{7}$.

A análise densitométrica assistida por computador pode ser útil na avaliação da mudança no conteúdo mineral ao longo do tempo, mas não permite comparações quantitativas entre diferentes áreas de interesse. Esta comparação necessitaria de um mecanismo de referência interna, como um penetrômetro, e o sistema que opera o CADIA não processa tal ferramenta para calibração ${ }^{28}$.

\subsection{Indução de doença periodontal em ratos}

A doença periodontal em humanos é difícil de ser estudada devido às grandes variações de resposta individual. Um modelo animal ideal para o 
estudo de periodontite parece ser o uso de primatas, mas as limitações de custo impedem o uso desses animais em estudos maiores. O rato (Rattus norvegicus) é, portanto o animal mais indicado para os estudos periodontais ${ }^{41}$.

Uma das principais vantagens do uso de ratos nestes estudos é o custo. No entanto, seu uso é justificado principalmente pela grande semelhança dos tecidos periodontais dos molares com os tecidos humanos, tanto em situação de normalidade quanto em situação de doença petriodontal $\left.\right|^{32,37,72}$.

A indução de doença periodontal em ratos foi realizada em vários estudos, com diferentes finalidades ${ }^{10,11,23,24,25,34,37,42,48,72}$. Diferentes mecanismos são utilizados para este fim, sendo mais comum o uso de uma ligadura ou fio atado ao redor da porção cervical do dente no qual se deseja induzir doença. Fios de algodão, seda e nylon foram utilizados, sendo relatada reabsorção óssea em alguns estudos ${ }^{10,11,55}$.

Em 1975, JOHNSON ${ }^{34}$ estudou os efeitos de injeções de dextransulfato em periodontite de ratos albinos. Induziu doença periodontal nos animais por meio da colocação de fio de seda ao redor do primeiro molar inferior direito, com o auxílio de uma mesa operatória própria ${ }^{12}$. Nos grupos que sofreram influência apenas do fio de seda, o autor notou que a reabsorção óssea da crista alveolar mesial ocorria principalmente por volta do $17^{\circ}$ dia e se tornava estável após o $27^{\circ}$ dia. 
KOIDE et al. ${ }^{42}$, em 1995, utilizou fio de seda 5-0 ao redor do segundo molar superior de ratos Wistar e encontrou reabsorção óssea inicial da crista alveolar após 3 dias, com pouca atividade osteoclástica até 14 dias.

Dois estudos utilizaram ligaduras de algodão por 30 dias em ratos Wistar adultos, encontrando destruição periodontal na região de furca ${ }^{23,48}$. No entanto, NOCITI Jr et al. ${ }^{48}$ não evidenciaram perda óssea significativa após 30 dias quando a análise foi quantificada por morfometria.

GONÇALVES et al. ${ }^{25}$, em 2003, em trabalho bastante semelhante ao de NOCITI Jr et al ${ }^{48}$, em 2000, utilizou período experimental de 45 dias, e encontrou diferença morfométrica significativa no volume de perda óssea entre o lado controle e o lado com ligadura de algodão.

Os achados microscópicos de doença periodontal induzida em ratos são vários e dependem do período experimental e do tipo de indução. Normalmente, com indução por ligadura, encontra-se epitélio juncional longo, abundância de células do tecido conjuntivo e vasos sangüíneos, perda das fibras do ligamento e fibras conjuntivas acima da crista óssea, infiltrado inflamatório, crista óssea irregular e reabsorvida, abundância de células do ligamento periodontal, presença de lacunas de Howship no cemento, seqüestro ósseo ${ }^{23,34}$.

A idade dos ratos para estudos periodontais é muito importante porque os molares estão completamente irrompidos a partir da $5^{\mathrm{a}}$ semana de vida ${ }^{46}$. Outro fator importante é que com a idade, ocorre migração distal dos molares e a distância entre a junção amelo-cementária e o topo da crista 
alveolar aumenta em algumas áreas linguais e palatais ${ }^{32,34}$. Por isso, a literatura recomenda utilizar animais de mesma idade para não alterar os resultados $^{2,41}$ 
Proposição 


\section{PROPOSIÇÃO}

Este trabalho teve como objetivos:

- Verificar as diferenças entre as médias dos valores dos pixels obtidas por meio de radiografias obtidas no sistema Digora e digitalizadas, feitas das áreas de indução de doença periodontal e áreas controles, nos períodos experimentais de 7, 14 e 28 dias, em ratos Wistar.

Comparar os resultados obtidos baseados nos valores dos pixels com uma análise histopatológica das mesmas áreas. 


$$
\begin{array}{r}
\text { Materiale } \\
\text { Métodos }
\end{array}
$$




\section{MATERIAL E MÉTODOS}

\subsection{Grupos experimentais}

O protocolo de pesquisa foi analisado pelo CEEPA (Comitê de Ética em Ensino e Pesquisa com Animais) da FOB e foi considerado aprovado em 04 de fevereiro de 2004 (anexo 1).

Um total de 30 ratos Wistar (Rattus norvegicus), fêmeas adultas, com 60 dias de idade, fornecidos pelo Biotério Central da Faculdade de Odontologia de Bauru, USP, foram divididos em três grupos, segundo a data de sacrifício:

Grupo 1: 10 animais, sacrificados aos 7 dias.

Grupo 2: 10 animais, sacrificados aos 14 dias.

Grupo 3: 10 animais, sacrificados aos 28 dias.

Os animais foram mantidos durante o período experimental em boas condições de higiene e alimentação, com ração e água ad libitum. 


\subsection{Material}

1. Dopalen injetável (Cloridrato de ketamina) e Anasedan injetável (Cloridrato de xilazina) fabricados por Agribrands do Brasil Ltda.

2. Pinças porta-agulhas.

3. Fios de sutura 3.0 (Ethicom®).

4. Formol a $10 \%$ tamponado.

5. Solução de EDTA pH 7,2 (4,13\% de Titriplex III Merck® e 0,44\% de hidróxido de sódio).

6. Álcool absoluto, xilol, corantes hematoxilina e eosina.

7. Lâminas de vidro e navalhas para micrótomo.

8. Filmes radiográficos tamanho 2 IP-21 Insight - Eastman Kodak®.

9. Aparelho radiográfico X-707, 70KVp e 7mA (Yoshida Dental MFC Co. Ltd., Tókio, Japão).

10. Luz de segurança com filtro GBX-2 (Kodak Company, New York, USA).

11. Soluções reveladora e fixadora de filmes radiográficos (Kodak Company, New York, USA).

12. Scanner a laser de 12 bits/pixel Lumiscan 50 (Lumisys Inc.) - LAPIMO E.E. - USP Campus de São Carlos.

13. Software ImageJ 1.29x (NIH - USA). 
14. Computador compatível com sistema Windows ${ }^{\circledR}$ (monitor de 17 polegadas, tela plana).

15. Sistema Digora ${ }^{\circledR}$, com placa de fósforo tamanho periapical, $40 \times 30 \mathrm{~mm}$ e software Digora for Windows ${ }^{\circledR}$ versão 1.50 (Orion / Soredex, Helsinki, Finland).

16. Microscópio óptico binocular Olympus $\mathrm{CH}$.

\subsection{Preparo dos animais I indução de doença periodontal}

Nos 30 animais (Grupos 1, 2 e 3), sob anestesia geral intramuscular, com Dopalen e relaxante muscular e sedativo de uso animal Anasedan, foi colocado um fio de sutura de seda 3-0 na cervical do primeiro molar inferior do lado direito (lado teste), para que houvesse acúmulo de placa e desenvolvimento de doença periodontal. O lado esquerdo foi deixado sem ligadura (lado controle). Os animais foram posicionados em uma mesa operatória própria para manter a boca aberta durante os procedimentos (figura 4.1). Esta mesa não é produzida em escala industrial e o exemplar utilizado pertence ao Departamento de Estomatologia da FOB - USP. Um aparato semelhante a este foi descrito por COSTICH, AVERY, HOEK ${ }^{12}$ em 1962. 
Utilizando pinças hemostáticas, as ligaduras foram introduzidas na face distal do primeiro molar inferior e um nó cirúrgico feito na face mesial, conforme ilustrado na figura 4.2 .

\subsection{Obtenção das peças cirúrgicas}

As ligaduras foram mantidas até a data do sacrifício. Na ocasião do sacrifício, com os animais ainda vivos, foram observados os aspectos clínicos a seguir, referentes ao primeiro molar que recebeu o fio de seda:

\begin{tabular}{|l|l|l|}
\hline Aspectos clínicos & \multicolumn{2}{|c|}{ Condição } \\
\hline Placa bacteriana & Ausente & Presente \\
\hline Sangramento ao toque & Ausente & Presente \\
\hline Edema gengival & Ausente & Presente \\
\hline
\end{tabular}

Os Grupos 1, 2 e 3 foram sacrificados ao término de períodos de 7, 14 e 28 dias, respectivamente, por dose excessiva de anestésico. Em seguida, as mandíbulas foram removidas por dissecção e corte com tesoura e divididas em duas partes (hemimandíbulas direita e esquerda). Os tecidos moles não foram completamente removidos, no intuito de simular uma imagem radiográfica das peças mais próxima de uma situação real. Os fios de seda foram removidos cuidadosamente com o uso de uma sonda exploradora e as peças submetidas então ao processo de fixação em formol $10 \%$ tamponado, durante uma semana. 


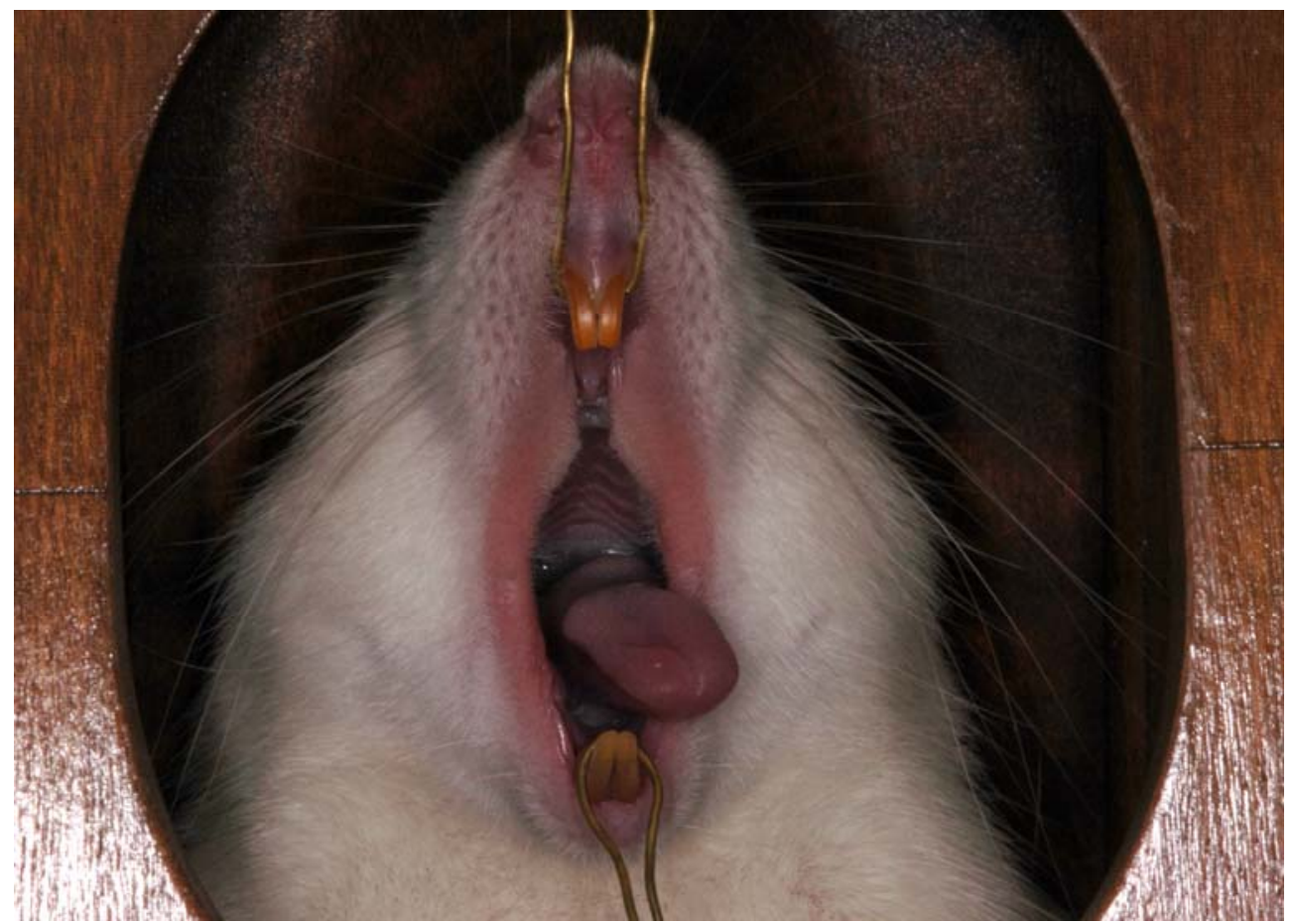

FIGURA 4.1: Posicionamento do rato na mesa operatória, com o dispositivo de abertura bucal.
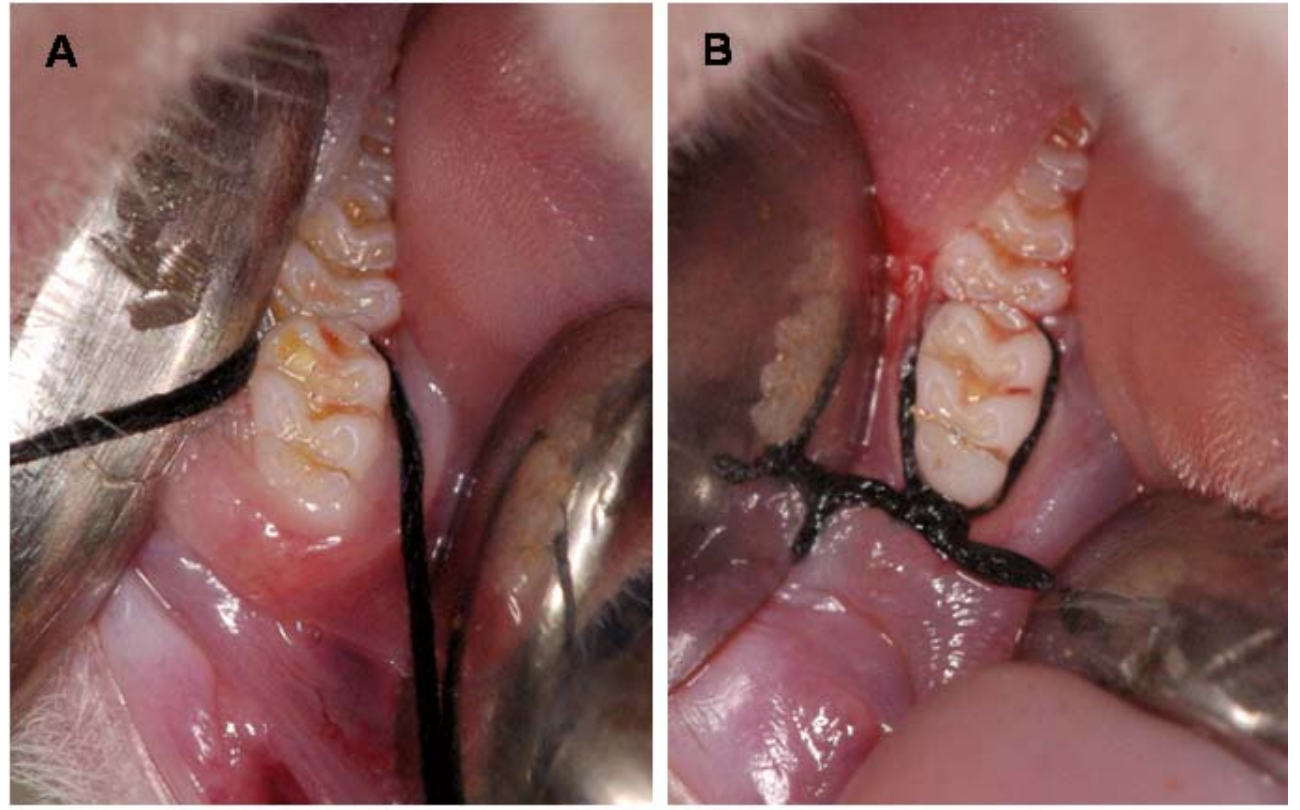

FIGURA 4.2: A: Colocação do fio de seda ao redor do primeiro molar inferior direito do rato. B: Aspecto final do fio de seda em posição. 

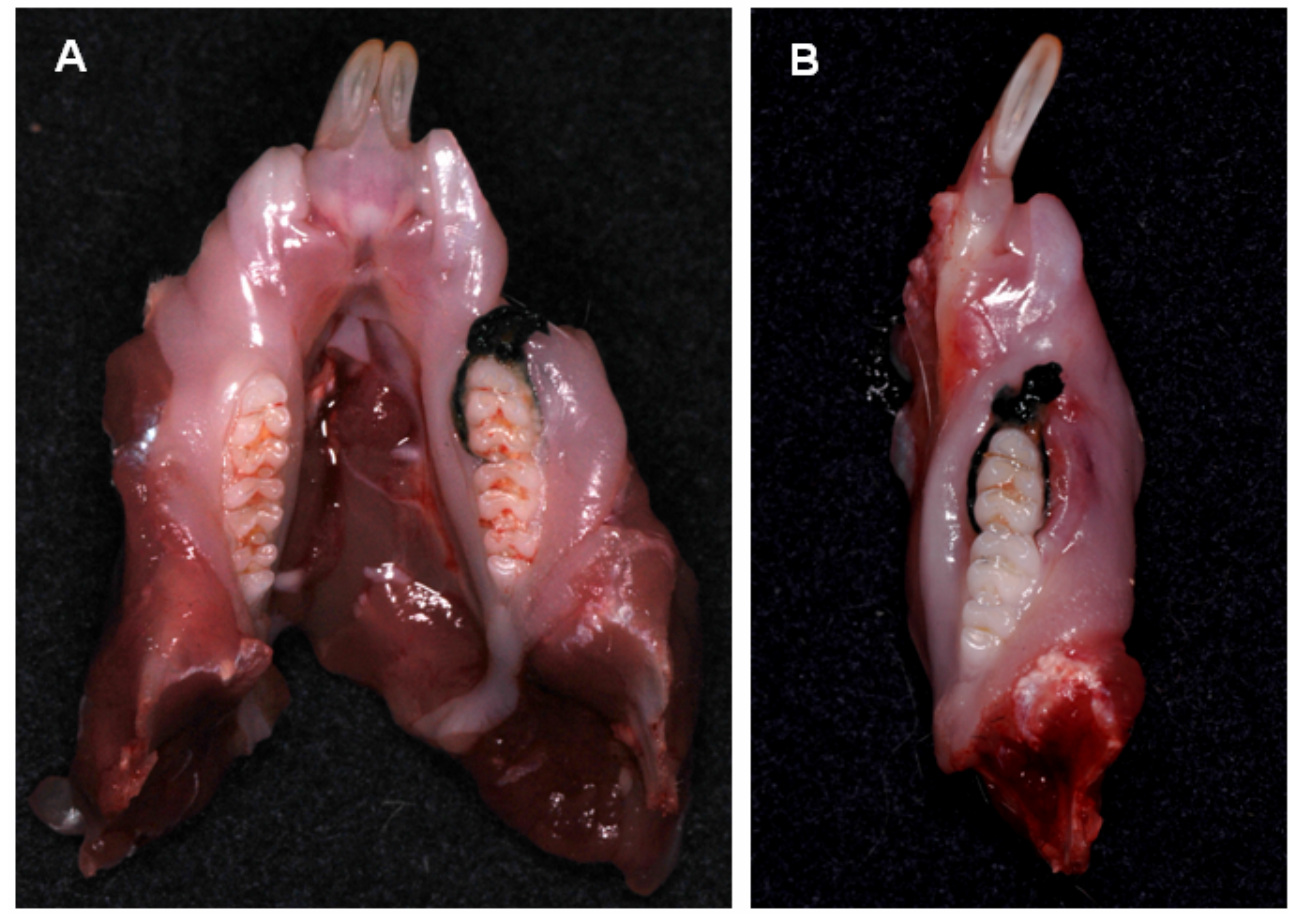

FIGURA 4.3: A: Mandíbula do rato removida. B: Detalhe do lado experimental ainda com o fio de seda em posição.

\subsection{Obtenção das imagens radiográficas}

Após a fixação das peças, foi realizado um teste piloto para ajuste do tempo de exposição correto para as tomadas radiográficas, no qual se estabeleceram tempos de exposição de 0,1 e 0,17 segundos para a placa de fósforo "blue" (Digora) e o filme radiográfico Insight (Kodak®), respectivamente. O sistema Digora foi calibrado previamente com um tempo de exposição de 0,5 segundo. 
As hemimandíbulas foram então radiografadas utilizando filmes radiográficos tamanho 2 (Kodak Insight), expostos segundo os parâmetros: $70 \mathrm{kVp}, 10 \mathrm{~mA}$, distância foco-filme de $30 \mathrm{~cm}$ e tempo de exposição de $0,17 \mathrm{~s}$, com o feixe de raios-x direcionado perpendicularmente às peças cirúrgicas. O aparelho de raios-X utilizado foi o X-707 (Yoshida Dental MFC Co. Ltd., Tókio, Japão)

As hemimandíbulas direita e esquerda pertencentes ao mesmo animal foram posicionadas sobre o filme radiográfico, o lado teste na esquerda e o lado controle na direita, de forma que a face lingual da peça ficasse em contato com a superfície do filme ${ }^{34,57}$. Um penetrômetro construído com 4 degraus de chumbo de películas radiográficas, segundo os parâmetros estabelecidos por WHITE, PHAROAH ${ }^{76}$, foi posicionado na porção do filme próxima ao picote, adjacente à hemimandíbula correspondente ao lado teste. Próximo ao penetrômetro, foi colocado um número de chumbo para identificação da radiografia, de 1 a 10 para cada grupo, de modo que as imagens obtidas seguiram o esquema ilustrado na figura 4.4.

As radiografias foram processadas obedecendo aos princípios do método manual (temperatura-tempo), com soluções novas.

Para a obtenção das radiografias digitais diretas, foi utilizado um sistema de obtenção por placa de fósforo "blue" (Digora), sendo a mesma placa utilizada para todas as aquisições, com tempo de exposição de 0,1 segundo. $O$ posicionamento das peças sobre a placa e do aparelho 
radiográfico foram os mesmos utilizados na obtenção das radiografias convencionais.

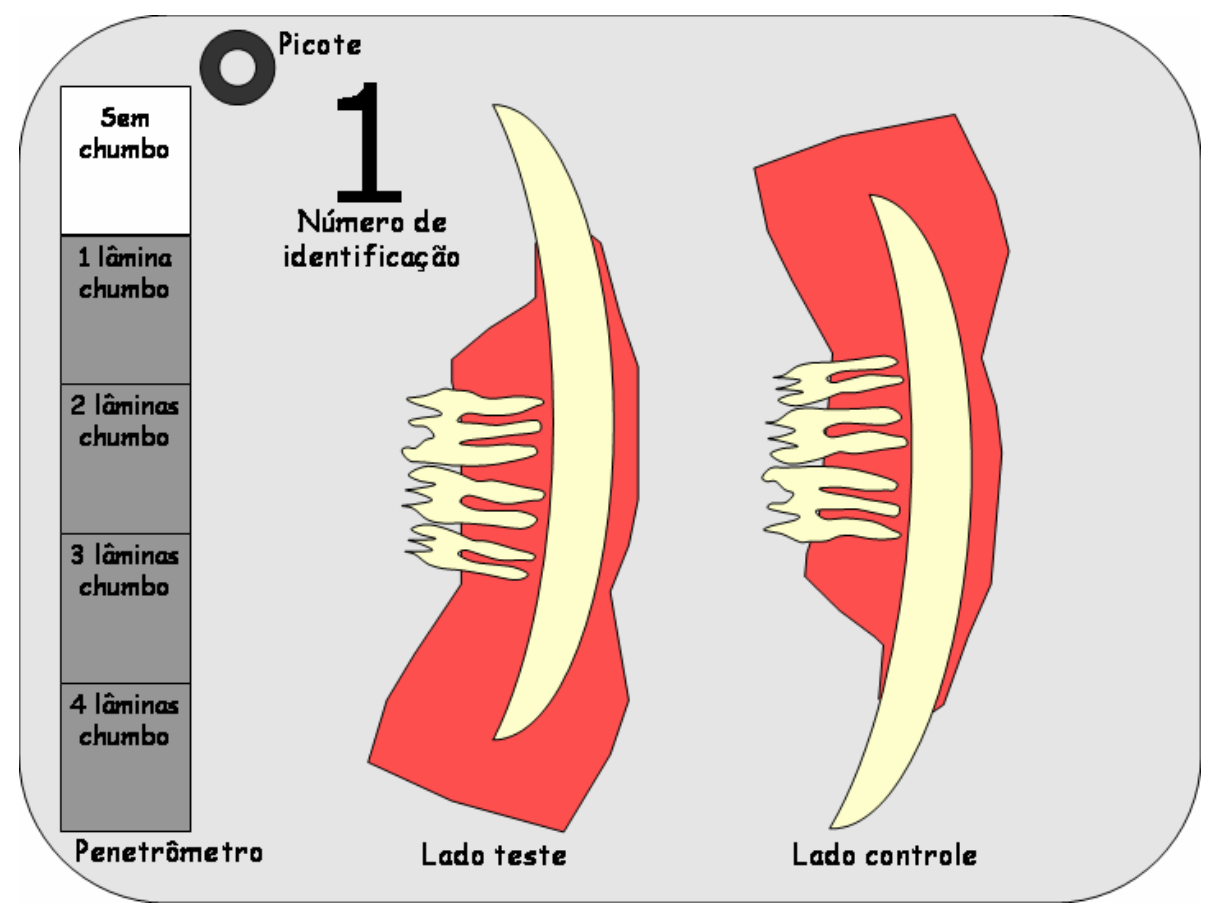

FIGURA 4.4: Esquema do posicionamento das peças cirúrgicas sobre o filme radiográfico e sobre a placa de fósforo para obtenção das imagens radiográficas.

Cada aquisição na placa de fósforo foi descarregada no sistema Digora por um escaneamento a laser, sempre no prazo máximo de 5 minutos após a exposição. As imagens armazenadas no software do Digora for Windows $\AA$, versão 1.50 , foram em seguida salvas no formato TIFF para possibilitar o processamento em outros softwares. Esses procedimentos forneceram imagens de 8 bits, com uma matriz de pixel de $560 \times 416$ e o 
tamanho do arquivo correspondente de 227 kbytes para cada imagem (figura4.5).

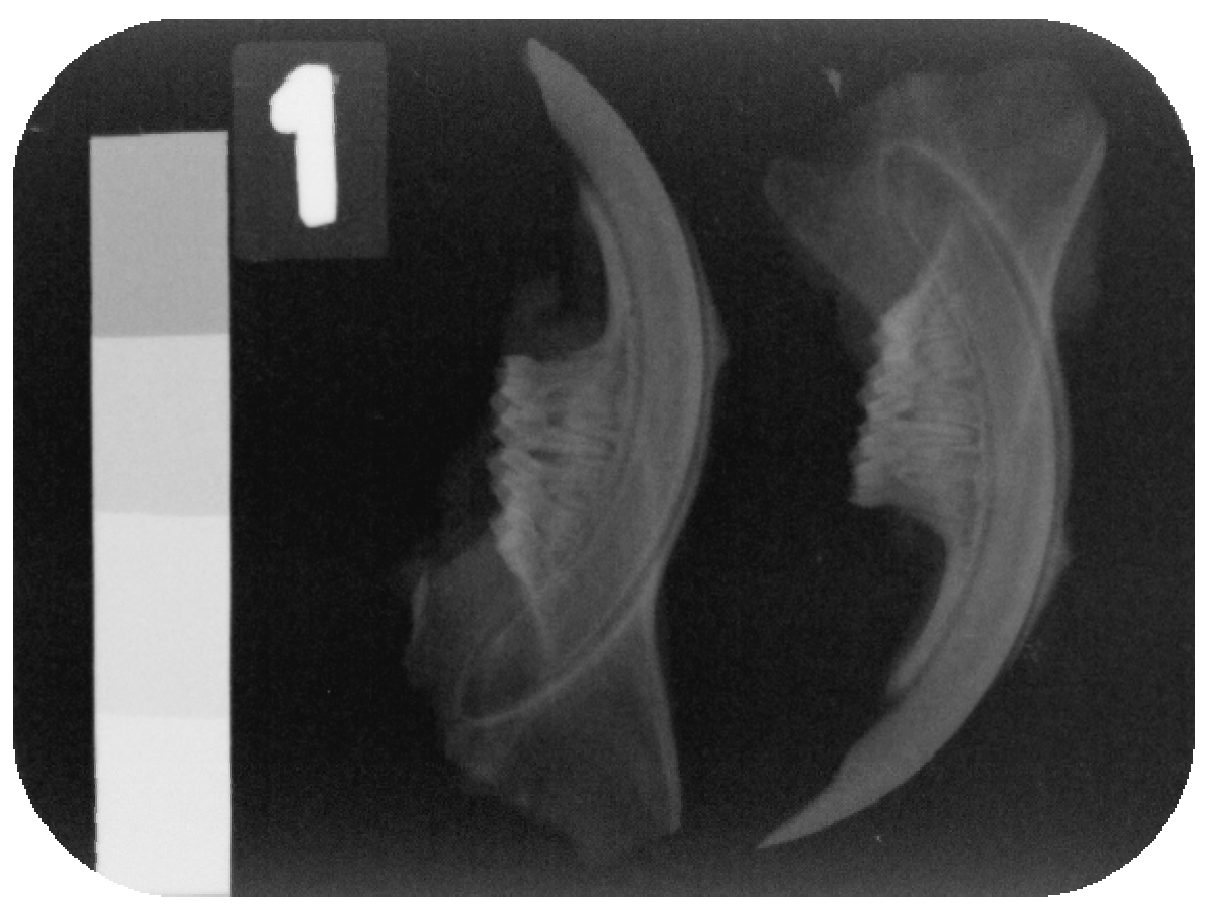

FIGURA 4.5: Imagem radiográfica digital obtida com a placa de fósforo do sistema Digora.

\subsection{Procedimentos histotécnicos}

Em seguida à obtenção e armazenamento das imagens radiográficas, procedeu-se à desmineralização das peças em solução de EDTA pH 7,2, preconizada por WARSHAWSKY, MOORE ${ }^{71}$, por um período de sessenta dias, com trocas semanais da solução. 
Após desmineralização comprovada por radiografias das peças, foi iniciado o procedimento histotécnico padrão do laboratório de Histologia da Faculdade de Odontologia de Bauru. As peças foram desidratadas, diafanizadas e incluídas em Paraplast. Cortes semi-seriados de $5 \mu \mathrm{m}$ de espessura foram obtidos no sentido mésio-distal das peças (micrótomo Jung-Leica RM2045) e corados pela técnica da Hematoxilina-Eosina. Procurou-se aproveitar as secções mais internas das peças, desprezando-se as porções mais linguais ou vestibulares.

\subsection{Análise dos valores dos pixels}

As radiografias obtidas pelo sistema digital direto Digora foram abertas no software Image J em um computador que opera com plataforma Windows, com monitor de 17 polegadas e tela plana. A sala foi escurecida durante a análise das radiografias para melhorar sua visualização. Uma área de medição de 30 pixels foi aberta no formato de um retângulo. Esta área correspondente à região de interesse $(\mathrm{RI})$ foi salva para que seu tamanho e formato pudessem ser mantidos em todas as medições. Uma outra área de medição de 3536 pixels foi igualmente criada e salva. Esta segunda área corresponde à região de controle $(\mathrm{RC})$, cujo objetivo foi medir as diferenças de histograma entre as tomadas radiográficas. 
Cada imagem foi aberta, ampliada duas vezes na tela, e a RI posicionada na crista alveolar mesial do primeiro molar, abaixo da junção amelo-cementária, no lado controle e no lado teste (figura 4.6), nessa mesma ordem. Foram solicitados os histogramas das Rls e os dados relativos às médias dos valores dos pixels foram tabulados. O histograma do software ImageJ forneceu os dados sobre média dos valores dos pixels numa escala de 8 bits (figura 4.7).

A

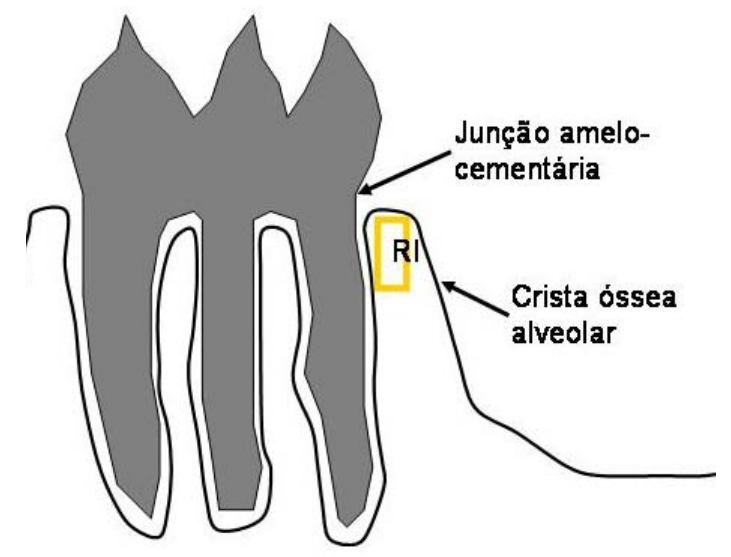

B

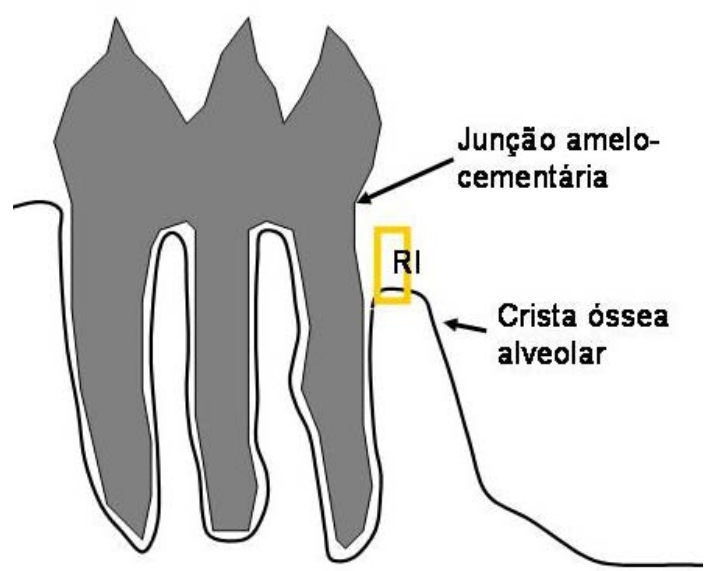

FIGURA 4.6: Posicionamento das regiões de interesse nas imagens radiográficas para medição do valor de pixel. A: lado controle. B: lado onde foi induzida doença periodontal.

Em cada radiografia, a $\mathrm{RC}$ foi posicionada na faixa mais central do penetrômetro, nas imagens sem aumento, e um novo histograma foi soliciado (figura 4.8). 


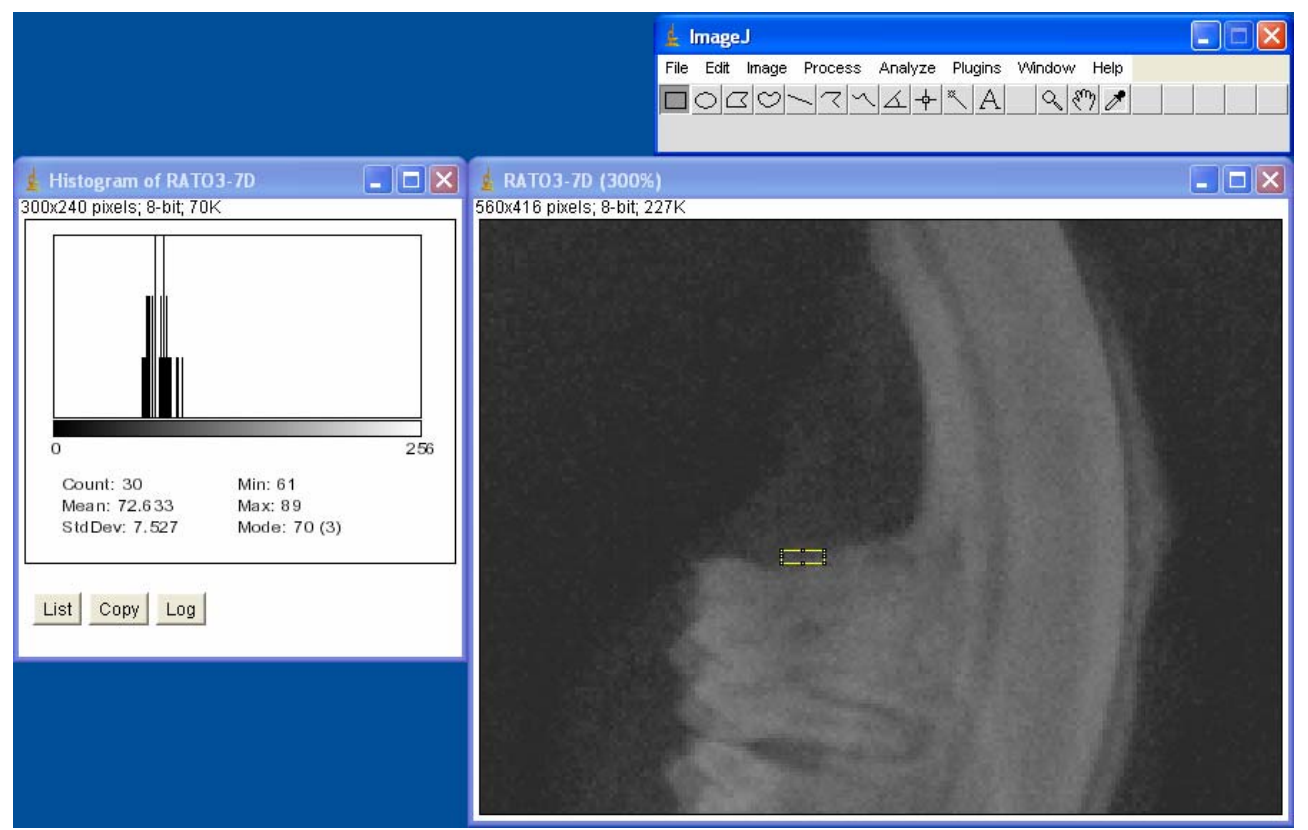

FIGURA 4.7: Medida do valor de pixel da região de interesse (RI) do sítio com doença periodontal de um rato do grupo 1.

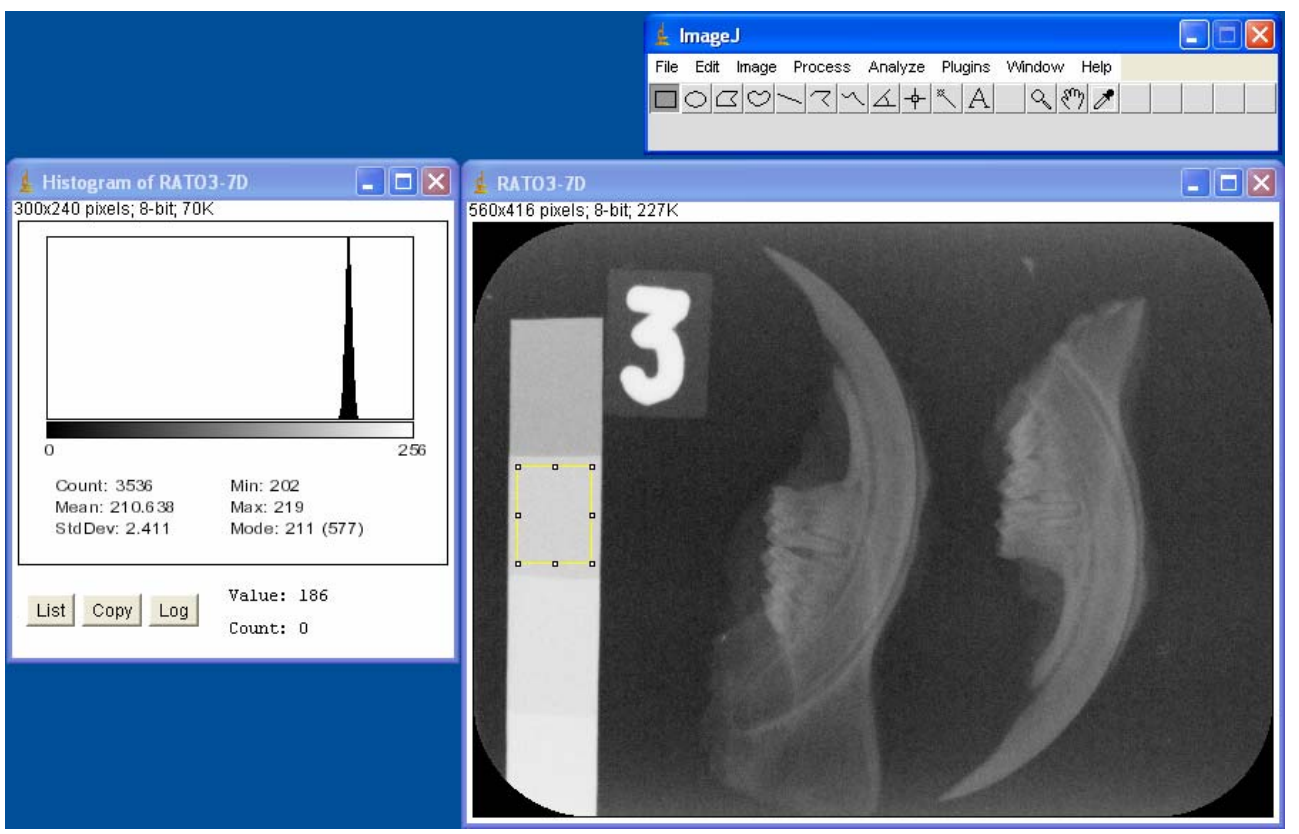

FIGURA 4.8: Medida do valor de pixel da região de controle $(R C)$ da radiografia do rato 3 do grupo 1 . 
As medidas das RIs foram obtidas pelo mesmo examinador e obedecendo à mesma técnica uma segunda vez após passados 15 dias, para a avaliação da concordância intra-examinador e obtenção da reprodutibilidade do método de medida de valor de pixel por meio do histograma.

As radiografias convencionais foram montadas em cartelas específicas para identificação e digitalizadas em um scanner a laser (12 bits). As imagens das cartelas de radiografias foram abertas no programa ImageJ, convertidas para 8 bits e cada radiografia foi recortada e transformada em um arquivo separado. Desta maneira, obtivemos 30 novas imagens. A medida dos valores dos pixels das RCs e das Rls foi realizada da mesma maneira que para as imagens digitais diretas, em uma área de medida fixa com tamanho de 5 pixels. Também foi feita uma segunda medida de todas as Rls para obtenção da concordância intra-examinador.

\subsection{Análise histopatológica}

Os cortes microscópicos obtidos foram observados em um microscópio binocular Olympus $\mathrm{CH} 2$, pelo mesmo examinador que trabalhou com as imagens digitais. O examinador foi previamente treinado para os parâmetros a serem analisados, observando e classificando cortes microscópicos aleatórios. 
Para cada hemimandíbula a ser analisada, foram escolhidos 5 cortes que melhor representassem a região de interesse. Para isso, procurou-se escolher cortes microscópicos que contivessem toda a raiz mesial do primeiro molar inferior e principalmente sua porção mais central, pois isto seria importante para a análise de altura da crista óssea. As lâminas foram identificadas novamente com uma seqüência numérica aleatória, mascarando a informação sobre quais seriam os períodos experimentais e sobre quais seriam os cortes do lado controle e lado teste. Os parâmetros microscópicos analisados tanto no lado teste quanto no lado controle estão listados na tabela 4.1 e detalhados abaixo.

TABELA 4.1: Características histopatológicas avaliadas nos sítios de doença periodontal e nos sítios controles.

\section{Característica histopatológicas}

1 Altura da crista óssea alveolar

2 Crista óssea alveolar

3 Crista óssea alveolar

4 Seqüestro ósseo

5 Fibras do tecido conjuntivo (acima da crista óssea)

6 Vasos do tecido conjuntivo (acima da crista óssea)

7 Intensidade do infiltrado inflamatório

8 Qualidade do infiltrado inflamatório
Condição histopatológica

1/3 cervical / 1/3 médio / 1/3 apical

Presença / Ausência de lacunas de Howship

Presença / Ausência de osteoclastos

Presença / Ausência

Esparsas / Quantidade moderada / Densas

Esparsos / Quantidade padrão / Abundância

Ausente / Leve / Moderado / Intenso

Polimorfonuclear / Misto / Mononuclear 
1. Altura da crista óssea alveolar: os cortes foram observados em aumento de 4 vezes e a raiz foi dividida visualmente em 3 terços, com o tamanho total da raiz indo da junção amelo-cementária (JAC) ao ápice. Para localização da JAC, o lado controle foi usado como parâmetro, uma vez que em condições normais, torna-se mais fácil a visualização do limite entre esmalte e cemento (figura 4.8). No lado doença, a JAC foi localizada pela presença de constrição na região. A altura da crista óssea foi classificada em terço cervical se o topo da crista estivesse no perímetro do terço cervical e assim por diante.

2 e 3. Lacunas de Howship na crista óssea e osteoclastos: esses dados foram analisados separadamente, pois poderiam existir lacunas vazias. Esses dois fatores foram analisados somente na porção mais cervical da crista óssea, tanto em sua porção mesial quanto na distal, em aumento de 10x e 40x.

4. Sequestro ósseo: foi considerado seqüestro ósseo da crista alveolar quando se observou, em aumento de 10X e 40X, fragmentos de tecido ósseo desconectados da crista óssea.

5. Fibras do tecido conjuntivo: foi avaliada a concentração de fibras na porção de tecido conjuntivo acima da crista óssea, em aumento de 10x, e os dados foram divididos em: 1 - esparsas, 2 - quantidade moderada, 3 densas 
6. Vasos do tecido conjuntivo: foi avaliada a concentração de vasos sangüíneos na porção de tecido conjuntivo acima da crista óssea, em aumento de $10 x$, e os dados foram ranqueados em: 1 - esparsos, 2quantidade padrão, 3 - abundância.

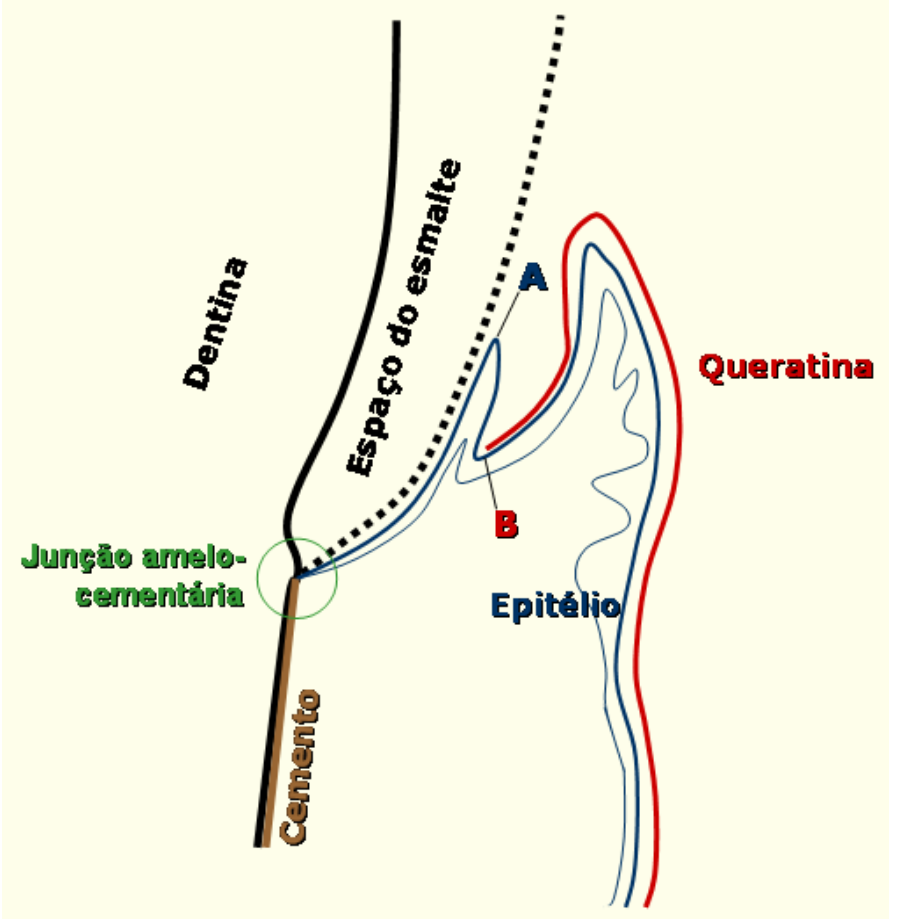

FIGURA 4.8: Diagrama da relação entre gengiva e junção amelo-cementária (JAC) na mesial do primeiro molar mandibular do rato. Epitélio não estratificado começa na JAC e vai até o ponto A. No ponto B inicia-se o epitélio queratinizado. Adaptado de JOHNSON ${ }^{34}, 1975$.

7. Intensidade do infiltrado inflamatório: foi avaliada, em aumento de 10x, a concentração de células inflamatórias na porção de tecido conjuntivo acima da crista óssea e adentrando o espaço do ligamento periodontal. Os dados 
foram ranqueados em: 1 - ausente (quantidade histologicamente normal de células), 2 - leve (células inflamatórias em pouca quantidade e restritas à região subepitelial), 3 - moderado (quantidade moderada de células inflamatórias espalhadas pelo tecido conjuntivo acima da crista óssea) , 4 intenso (grande quantidade de células inflamatórias espalhadas pelo tecido conjuntivo acima da crista óssea e no espaço do ligamento periodontal)

8. Tipo de infiltrado inflamatório: o infiltrado avaliado em aumento de $40 x$ foi dividido em 0 (zero) - infiltrado inflamatório ausente; 1 - polimorfonuclear (quando a quantidade de polimorfonucleares superava bastante a quantidade de mononucleares), 2 - misto (quando as quantidades de polimorfonucleares e mononucleares eram semelhantes), 3 - Mononuclear (quando a quantidade de mononucleares superava bastante a quantidade de polimorfonucleares).

\subsection{Análise estatística}

As médias dos valores dos pixels das radiografias digitais diretas e indiretas foram submetidas à ANOVA a dois critérios, sendo os critérios o tempo e a condição de doença periodontal. A ANOVA a um critério foi utilizada para avaliar as diferenças entre as médias dos valores dos pixels das áreas de doença periodontal entre os grupos. A correlação intra- 
examinador foi avaliada pela medida do erro casual e do erro sistemático, com o uso dos testes de Dahlberg, "t" pareado e correlação de Pearson ${ }^{31}$.

Os resultados microscópicos dicotômicos foram expressos descritivamente e os resultados das medidas por escores submetidos ao teste não-paramétrico de Wilcoxon (grupos pareados). 


\section{Resultados}




\section{RESULTADOS}

Dos 30 ratos inicialmente na amostra, foram perdidos apenas 3 , por morte prematura e por deslocamento do fio de seda. Esses 3 animais foram substituídos por outros de mesma idade, sem perdas para o experimento. 0 método de indução de doença periodontal foi eficaz no acúmulo de placa e restos alimentares (figuras 5.1 a 5.3), causando edema e sangramento (tabela 5.1).

TABELA 5.1: Presença de placa bacteriana, edema e sangramento gengival na região do fio de sutura posicionado no lado experimental. Valores expressos em porcentagens de ratos que apresentavam as características observadas.

\begin{tabular}{cccc}
\hline Grupo & Placa bacteriana & Edema gengival & Sangramento gengival \\
\hline 1 & $90 \%$ & $90 \%$ & $40 \%$ \\
2 & $100 \%$ & $50 \%$ & $50 \%$ \\
3 & $100 \%$ & $30 \%$ & $40 \%$ \\
\hline
\end{tabular}




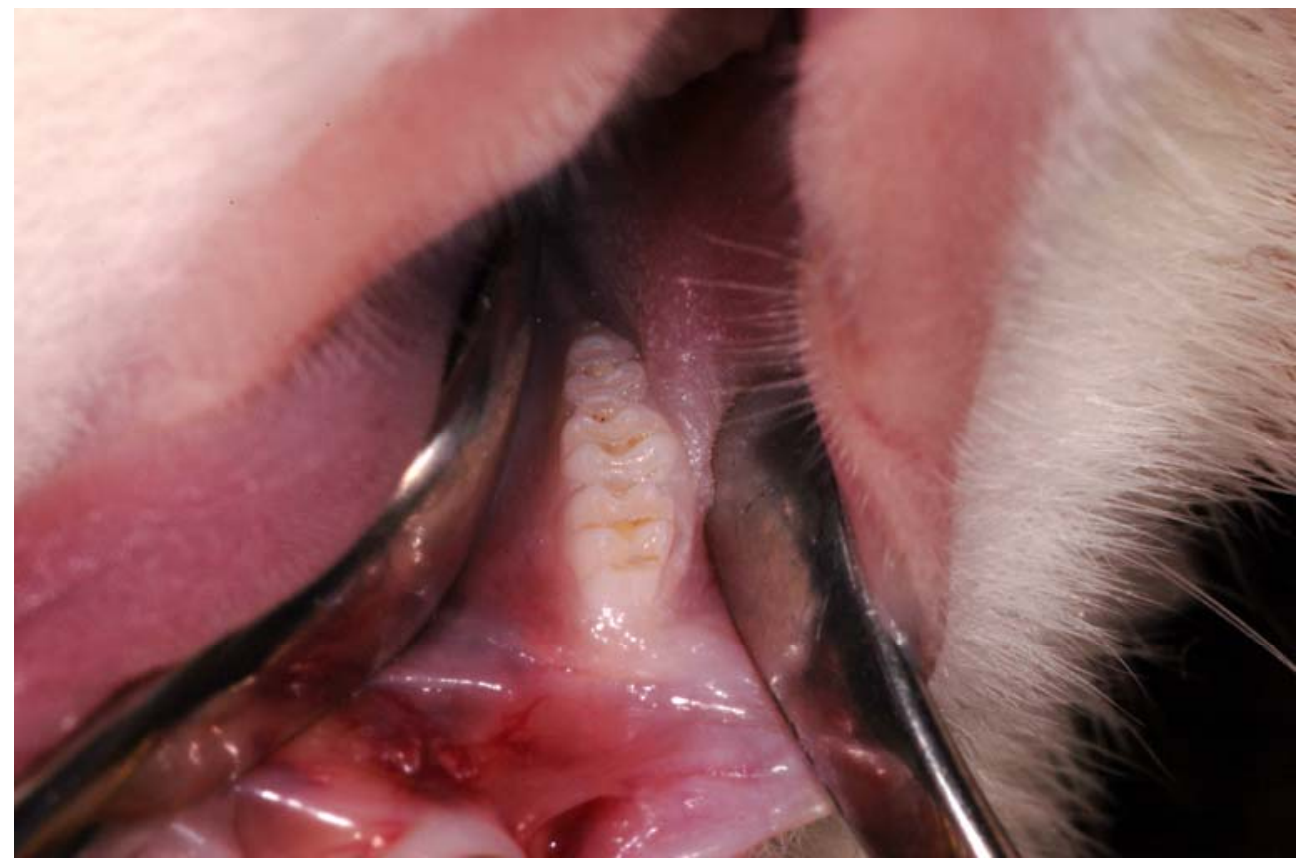

FIGURA 5.1: Sítio controle de um rato do grupo 1 (7 dias). Nota-se ausência de sinais inflamatórios na região do primeiro molar inferior.

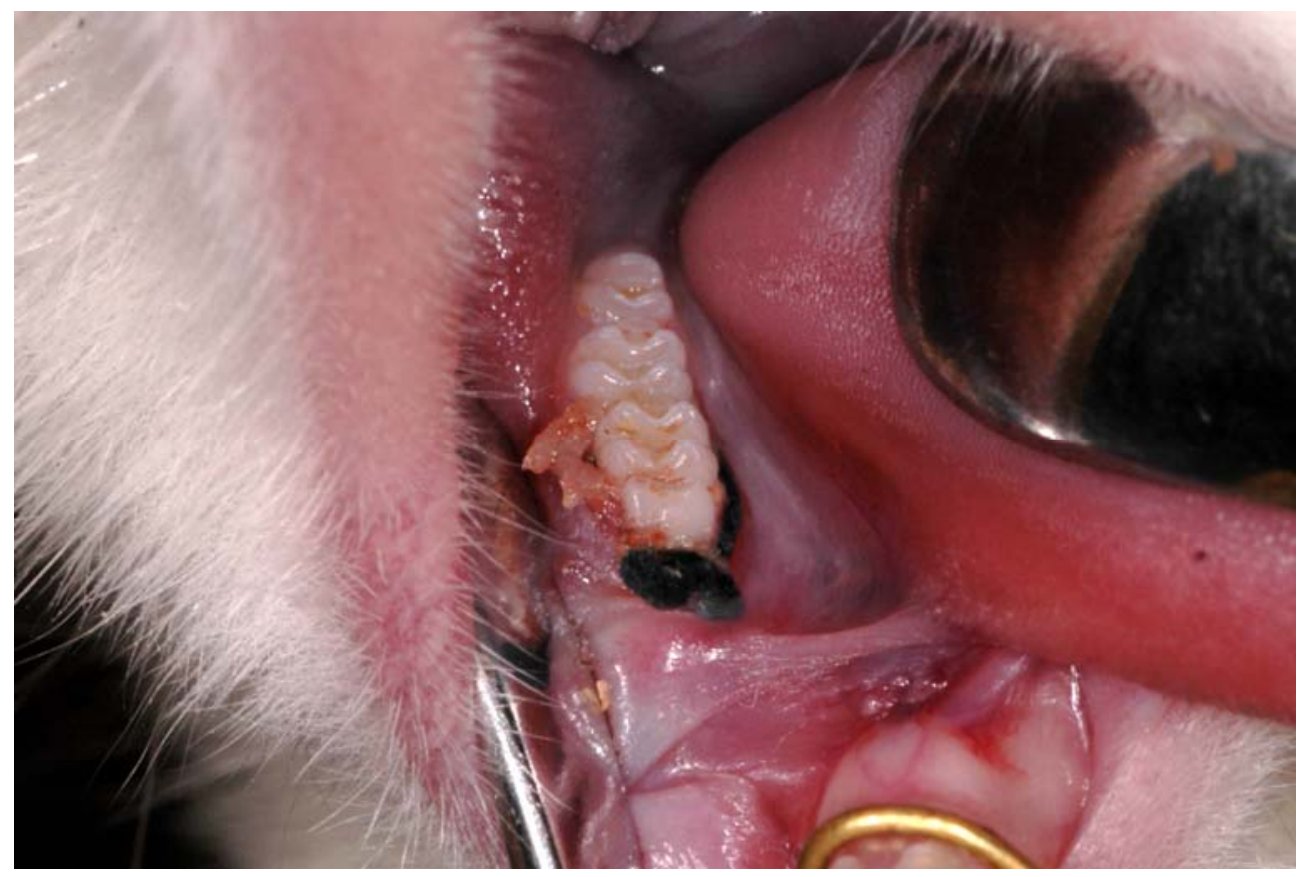

FIGURA 5.2: Região onde foi induzida doença periodontal no mesmo rato mostrado na figura 5.1. Acúmulo de restos alimentares no primeiro molar. 


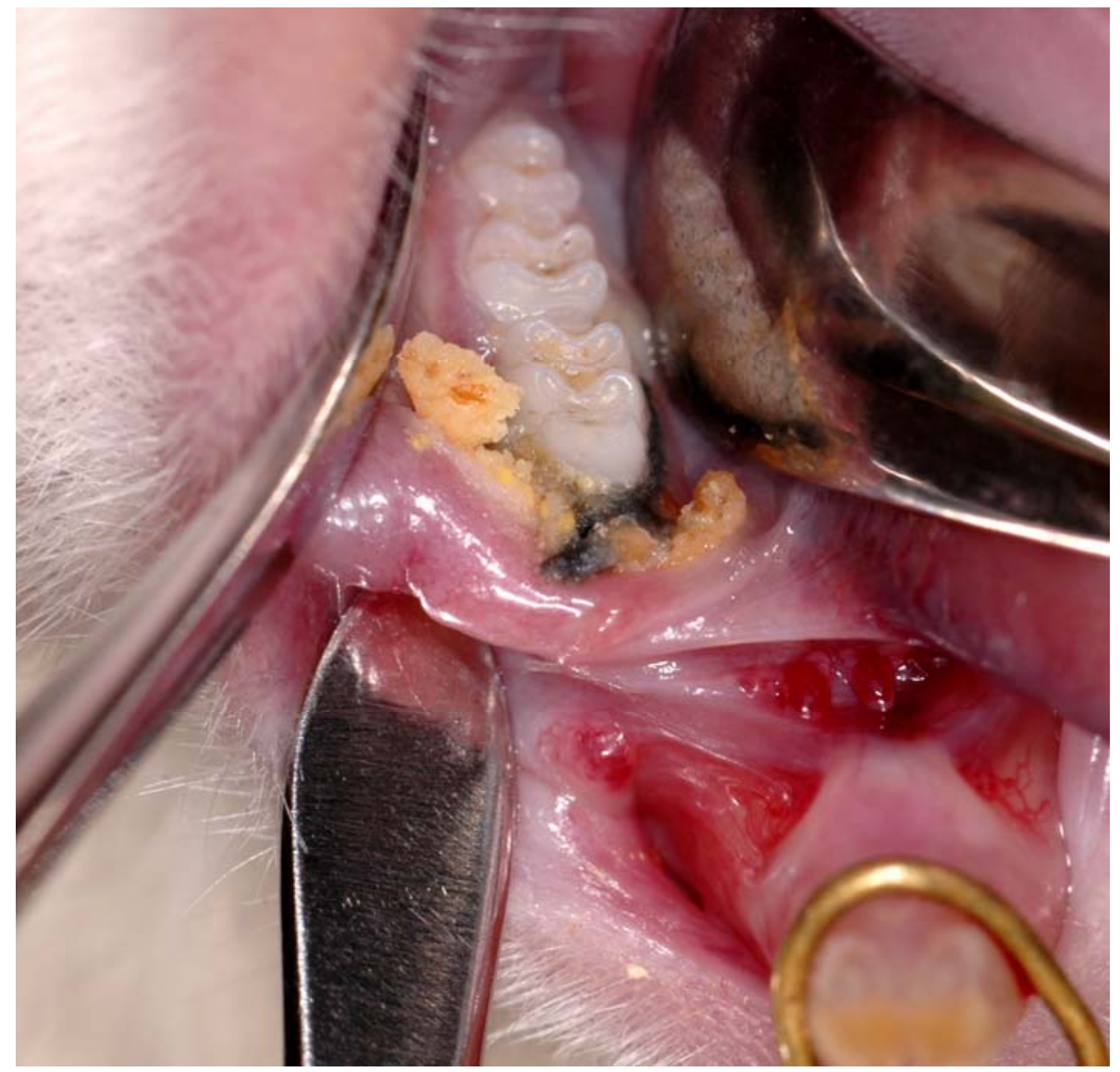

FIGURA 5.3: Sítio onde houve indução de doença periodontal em um rato do grupo 3 (28 dias de indução). Nota-se grande acúmulo de restos alimentares junto ao fio de sutura.

\subsection{Análise das imagens obtidas no sistema Digora}

Depois de radiografadas as peças, as regiões de controle (RCs) foram analisadas conforme descrito na metodologia. Foram medidas $30 \mathrm{RCs}$, uma para cada radiografia, ou seja, a mesma RC se aplicava para o lado controle e o lado doença de cada animal. As médias das regiões de controle em cada grupo estão descritas na tabela 5.2. 
TABELA 5.2 - Médias e desvios-padrão dos valores dos pixels das regiões de controle das radiografias obtidas no sistema Digora, discriminados por grupo.

\begin{tabular}{ccc}
\hline Grupo & Média dos valores dos pixels & $\mathbf{d p}$ \\
\hline 1 & 208,90 & 2,48 \\
2 & 210,20 & 1,09 \\
3 & 212,98 & 1,68 \\
\hline
\end{tabular}

Uma vez que a média dos valores dos pixels das regiões de controle foram bastante semelhantes entre si, dentro de cada grupo, optamos por não utilizar nenhum fator de correção baseado nessa variabilidade. Esse fator de correção, se empregado, seria aplicado igualmente para corrigir o valor do lado controle e do lado teste na mesma magnitude, pois ambos estão localizados na mesma radiografia. As regiões de controle foram úteis para nos indicar que as radiografias feitas no sistema Digora foram bastante semelhantes entre si, e, portanto, possíveis de serem analisadas em conjunto.

O valor de pixel das cristas ósseas foi obtido da mesma maneira que para as regiões de controle, ou seja, confeccionando-se uma área de seleção e aplicando-a nas áreas de interesse no lado controle e no lado experimental. As médias dos valores dos pixels obtidas para cada grupo estão descritos na tabela 5.3 . 
TABELA 5.3 - Médias e desvios-padrão (dp) dos valores dos pixels das regiões de interesse das radiografias obtidas com o sistema Digora, distribuídas entre os grupos e condição periodontal.

\begin{tabular}{ccccc}
\hline Grupo & Condição & Média (pixels) & dp (pixels) & $\mathbf{n}$ \\
\hline 1 & C & 67,5 & 12,9 & 10 \\
1 & DP & 61,2 & 12,3 & 10 \\
2 & C & 73,1 & 11,5 & 10 \\
2 & DP & 51,9 & 6,4 & 10 \\
3 & C & 85,3 & 7,6 & 10 \\
3 & DP & 69.8 & 7,5 & 10 \\
\hline
\end{tabular}

C - controle; DP - doença periodontal

A análise das médias de cada grupo mostrou que os valores dos pixels nos lados onde a doença periodontal foi induzida diminuíram, indicando perda óssea. A comparação das médias dos valores dos pixels entre grupos pela ANOVA (análise de variância) a dois critérios mostrou que esta diminuiçao do valor de pixel nos lados doença periodontal foi estatisticamente significante $(p=0,000001)$ para todos os intervalos de tempo, ou seja, para todos os grupos.

Para analisar a influência da variável tempo na condição de doença periodontal apenas, a ANOVA a um critério e teste de Tukey foram aplicados, demonstrando haver um aumento estatisticamente significativo $(p=0,00069)$ na média dos valores dos pixels do grupo de 14 dias para $\circ$ grupo de 28 dias, nas regiões de doença periodontal (tabela 5.4). 
A influência da variável tempo sobre as regiões periodontais de controle foi avaliada por meio da ANOVA a um critério e teste de Tukey, demonstrando haver aumento do valor de pixel do grupo 1 para o grupo 3 e do grupo 2 para o grupo 3, este aumento foi estatisticamente significante $(p=0,00069)$, conforme a tabela 5.5.

TABELA 5.4 - Teste de Tukey para a variável tempo: significância estatística entre as médias dos valores dos pixels dos diferentes intervalos de tempo (grupos 1, 2 e 3 ), para medidas obtidas nas áreas de doença periodontal em radiografias obtidas no sistema Digora.

\begin{tabular}{ccc}
\hline Comparação & Diferença & Interpretação \\
\hline Grupo 1 x Grupo 2 & 9,2 & não significante \\
Grupo 1 x Grupo 3 & $-8,7$ & não significante \\
Grupo 2 x Grupo 3 & $-17,9$ & significante \\
\hline
\end{tabular}

Nível de significância $=5 \%$, Valor crítico $=10,11$

TABELA 5.5 - Teste de Tukey para a variável tempo: significância estatística entre as médias dos valores dos pixels dos diferentes intervalos de tempo (grupos 1, 2 e 3 ), para medidas obtidas nas áreas de controle periodontal em radiografias obtidas no sistema Digora ${ }^{\circledR}$.

\begin{tabular}{ccc}
\hline Comparação & Diferença & Interpretação \\
\hline Grupo 1 x Grupo 2 & $-5,6$ & não significante \\
Grupo 1 x Grupo 3 & $-17,7$ & significante \\
Grupo 2 x Grupo 3 & $-12,1$ & significante \\
\hline
\end{tabular}

Nível de significância $=5 \%$, Valor crítico $=12,08$ 
Para obtenção da concordância intra-examinador, as medidas de valor de pixel foram repetidas pelo mesmo examinador após 15 dias. A concordância entre a primeira e a segunda medidas foi obtida pela avaliação do erro sistemático e do erro casual.

$\mathrm{O}$ erro sistemático foi medido através do teste " $\mathrm{t}$ " pareado ( $\mathrm{t}$ ) e do coeficiente de correlação de Pearson ( $r$ ) entre as 60 primeiras medidas (somando-se as medidas de controle e doença periodontal) e as 60 medidas consecutivas, o que resultou em um valor de $t=3,246(p=0,002)$ e valor de $r=0,87$. O teste "t" pareado foi estatisticamente significativo em demonstrar diferenças entre a primeira e a segunda medidas, no entanto, esta diferença foi bastante pequena, sendo a primeira medida menor que a segunda em 2,22 pixels em média, valor não importante do ponto de vista prático. 0 coeficiente de correlação de Pearson foi considerado forte, pois quanto mais próximo de 1 for o valor de $\mathrm{r}$, mais forte é a concordância entre as variáveis.

O erro casual foi medido pelo Teste de Dahlberg, que forneceu um valor de erro correspondente a 5,63 pixels. Este erro foi pequeno, se levarmos em consideração que as médias dos valores dos pixels variaram entre 51,9 e 85,3 . 


\subsection{Análise das imagens digitais indiretas}

A mesma forma de análise estatística foi aplicada para as imagens obtidas por digitalização indireta das radiografias convencionais. As medidas dos valores dos pixels nas regiões de controle evidenciaram pequena variação entre as imagens, como pode ser visto na tabela 5.6.

Os valores dos pixels das cristas ósseas foram obtidos da mesma maneira que para as radiografias digitais diretas. As médias dos valores dos pixels obtidas para cada grupo estão descritos na tabela 5.7 .

A comparação das médias dos valores dos pixels pela ANOVA (análise de variância) a dois critérios, sendo eles o tempo experimental (7, 14 ou 28 dias) e a condição (controle ou doença periodontal) evidenciou diferença estatisticamente significativa $(p=0,000000)$ entre as médias do lado controle e as médias do lado experimental para os três grupos, um resultado bastante semelhante ao encontrado para as medidas obtidas por radiografias digitais diretas. Essas diferenças também corresponderam a uma diminuição no valor de pixel nos lados de doença para todos os grupos.

Para analisar a influência da variável tempo na condição de doença periodontal apenas, a ANOVA a um critério e o teste de Tukey foram aplicados, demonstrando não haver diferença estatisticamente significante na média dos valores dos pixels entre os três grupos (tabela 5.8). 
TABELA 5.6 - Médias e desvios-padrão dos valores dos pixels das regiões de controle das radiografias digitais indiretas, discriminados por grupo.

\begin{tabular}{ccc}
\hline Grupo & Média valor pixel & $\mathbf{d p}$ \\
\hline 1 & 209,66 pixels & 1,86 \\
2 & 210,52 pixels & 1,62 \\
3 & 209,96 pixels & 1,18 \\
\hline
\end{tabular}

TABELA 5.7 - Médias e desvios-padrão (dp) dos valores dos pixels das regiões de interesse das radiografias convencionais, distribuídas entre os grupos e condição periodontal.

\begin{tabular}{ccccc}
\hline Grupo & Condição & Média (pixels) & dp (pixels) & $\mathbf{n}$ \\
\hline 1 & C & 112,4 & 6,9 & 10 \\
1 & DP & 107,4 & 4,8 & 10 \\
2 & C & 115,7 & 2,9 & 10 \\
2 & DP & 106,9 & 3,7 & 10 \\
3 & C & 120,6 & 4,1 & 10 \\
3 & DP & 109,1 & 2,0 & 10 \\
\hline
\end{tabular}

C - controle; DP - doença periodontal

A ANOVA a um critério e teste de Tukey demonstraram haver aumento estatisticamente significante do valor de pixel do grupo 1 para o grupo 3 e do grupo 2 para o grupo $3(p=0,00069)$ para as regiões de controle periodontal (tabela 5.9). 
TABELA 5.8 - Teste de Tukey para a variável tempo: significância estatística entre as médias dos valores dos pixels dos diferentes intervalos de tempo (grupos 1, 2 e 3 ), para medidas obtidas nas áreas de doença periodontal em radiografias digitais indiretas.

\begin{tabular}{ccc}
\hline Comparação & Diferença & Interpretação \\
\hline Grupo 1 x Grupo 2 & 0,4 & não significante \\
Grupo 1 x Grupo 3 & $-1,7$ & não significante \\
Grupo 2 x Grupo 3 & $-2,1$ & não significante \\
\hline
\end{tabular}

Nível de significância $=5 \%$, Valor crítico $=4,09$

TABELA 5.9 - Teste de Tukey para a variável tempo: significância estatística entre as médias dos valores dos pixels dos diferentes intervalos de tempo (grupos 1, 2 e 3 ), para medidas obtidas nas áreas de controle periodontal em radiografias digitais indiretas.

\begin{tabular}{ccc}
\hline Comparação & Diferença & Interpretação \\
\hline Grupo 1 x Grupo 2 & $-2,2$ & não significante \\
Grupo 1 x Grupo 3 & $-7,2$ & significante \\
Grupo 2 x Grupo 3 & $-4,9$ & não significante \\
\hline
\end{tabular}

Nível de significância $=5 \%$, Valor crítico $=5,85$

Assim como para as radiografias digitais diretas, a concordância intraexaminador das medidas das radiografias digitais indiretas foi obtida, utilizando-se os mesmos meios de análise. $\mathrm{O}$ erro sistemático medido por 
meio do teste "t" pareado foi estatisticamente significativo ao demonstrar diferenças entre a primeira e a segunda medidas ( $" \mathrm{t} "=3,31, p=0,002$ ). No entanto, esta diferença foi bastante pequena, sendo a primeira medida menor que a segunda em 1,34 pixels em média. O coeficiente de correlação de Pearson foi considerado forte $(r=0,88)$.

O erro casual, medido pelo Teste de Dahlberg, foi de 2,39 pixels. Este erro foi pequeno, ainda menor que o encontrado para as radiografias digitais diretas.

\subsection{Análise histopatológica}

Para os 10 ratos de cada grupo, foram obtidas 20 peças cirúrgicas. Para cada peça, foram analisados 5 cortes microscópicos semi-seriados, o que soma 100 cortes em cada grupo.

As lâminas foram re-identificadas aleatoriamente para diminuir o erro na análise. Mesmo com esse procedimento, foi fácil durante a análise supor qual seria o lado controle e o lado doença, pois as diferenças microscópicas eram bastante óbvias. No entanto, a re-identificação das lâminas foi útil no mascaramento entre os grupos, pois era especialmente difícil supor qual seria o grupo 2 e qual seria o grupo 3 , nos lado doença. 
Para a análise estatística, foi preciso obter novamente um único resultado para cada peça analisada. Para tal, foram agrupados os resultados dos cinco cortes analisados em cada peça. Para os critérios com resultados fornecidos em escores, foi obtida a média dos escores dos cinco cortes. Para os demais critérios, foi considerada a ocorrência mais freqüente como sendo o resultado.

Os resultados serão descritos para cada parâmetro microscópico analisado, nas tabelas 5.10 a 5.16 .

A altura da crista óssea mostrou diminuição do grupo 1 para o grupo 3, migrando cada vez mais para apical e tornando-se cada vez mais diferente de seus controles com o passar do tempo experimental (tabela 5.10 e figura 5.4).

A atividade reabsortiva do osso foi analisada verificando a quantidade de osteoclastos e lacunas de Howship na crista óssea, conforme observado na tabela 5.11. Foi observada maior presença de osteoclastos nos lados de doença que nos seus controles e esta quantidade diminuiu com o passar do tempo, ou seja, houve maior presença de clastos no grupo de 7 dias do que no grupo de 28 dias (figura 5.5). Esse resultado se repete quando analisamos a presença de lacunas de Howship na crista óssea. 
TABELA 5.10 - Altura da crista óssea, avaliada histologicamente, separada por grupo e condição. Valores expressos em números absolutos de áreas observadas.

\begin{tabular}{ccccc}
\hline \multirow{2}{*}{ Grupo } & Condição & \multicolumn{4}{c}{ Altura da crista óssea } \\
& & $1 / 3$ cervical $(\mathrm{n})$ & $1 / 3$ médio $(\mathrm{n})$ & $1 / 3$ apical $(\mathrm{n})$ \\
\hline 1 & $\mathrm{C}$ & 10 & 0 & 0 \\
1 & DP & 2 & 8 & 0 \\
2 & $\mathrm{C}$ & 10 & 0 & 0 \\
2 & DP & 0 & 6 & 4 \\
3 & $\mathrm{C}$ & 10 & 0 & 0 \\
3 & DP & 0 & 4 & 6 \\
\hline C - lado controle, DP - lado doença periodontal & &
\end{tabular}

TABELA 5.11 - Classificação microscópica da presença de lacunas de Howship e osteoclastos. Valores expressos em números absolutos de áreas observadas e separados por grupo e condição.

\begin{tabular}{|c|c|c|c|c|c|}
\hline \multirow[b]{2}{*}{ Grupo } & \multirow[b]{2}{*}{ Condição } & \multicolumn{2}{|c|}{ Lacuna de Howship osso } & \multicolumn{2}{|c|}{ Osteoclastos } \\
\hline & & $\begin{array}{c}\text { Presente } \\
\text { (n) }\end{array}$ & $\begin{array}{c}\text { Ausente } \\
\text { (n) }\end{array}$ & $\begin{array}{c}\text { Presente } \\
\text { (n) }\end{array}$ & $\begin{array}{c}\text { Ausente } \\
\text { (n) }\end{array}$ \\
\hline 1 & C & 3 & 7 & 0 & 10 \\
\hline 1 & $\mathrm{DP}$ & 10 & 0 & 10 & 0 \\
\hline 2 & $\mathrm{C}$ & 4 & 6 & 0 & 10 \\
\hline 2 & $\mathrm{DP}$ & 7 & 3 & 4 & 6 \\
\hline 3 & $\mathrm{C}$ & 0 & 10 & 0 & 10 \\
\hline 3 & $\mathrm{DP}$ & 2 & 8 & 1 & 9 \\
\hline
\end{tabular}

C - lado controle, DP - lado doença periodontal 

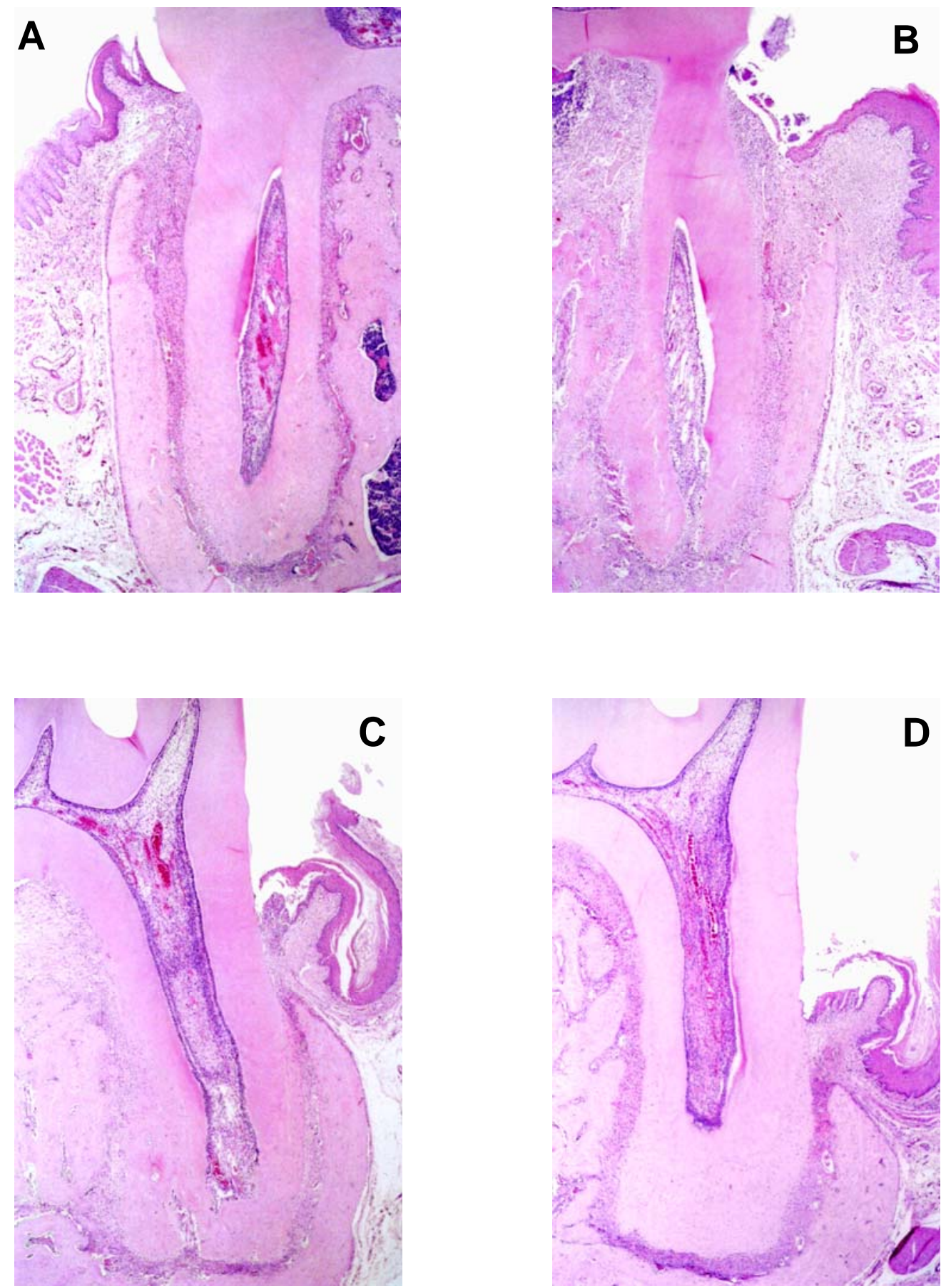

FIGURA 5.4: Altura da crista óssea. A: Sítio controle, rato do grupo 1. B: Sítio doença periodontal, rato do grupo 1 (crista óssea no terço cervical da raiz). C: Sítio doença periodontal, rato do grupo 2 (crista óssea no terço médio da raiz). D: Sítio doença periodontal, rato do grupo 3 (crista óssea no terço apical da raiz). HE, 30x. 


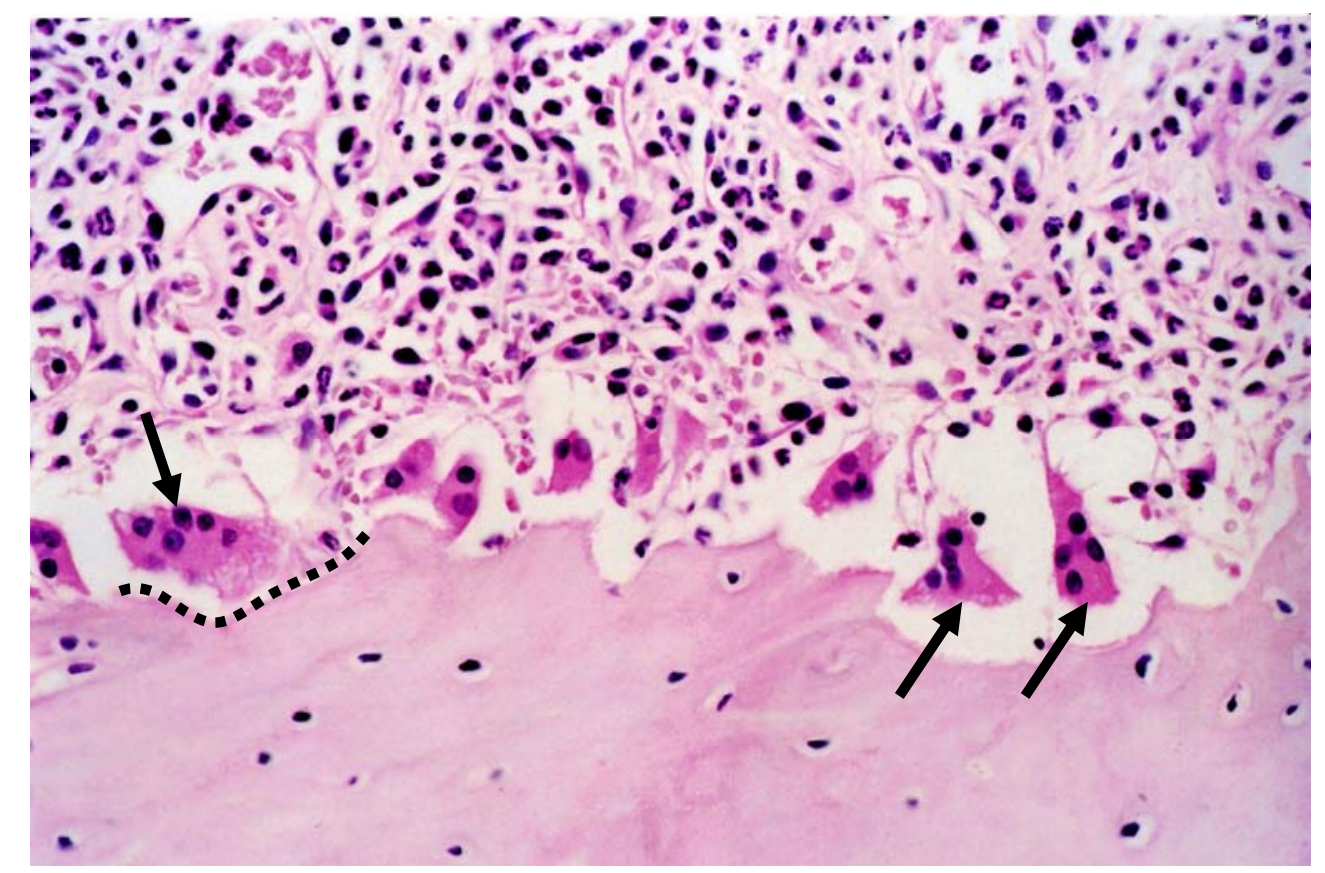

FIGURA 5.5: Presença de osteoclastos (setas) e lacunas de Howship (pontilhado) na crista óssea alveolar em sítio de doença periodontal de um rato do grupo de 7 dias. HE, 475x.

Houve ausência de seqüestros ósseos nos lados controle e sua presença decresceu do grupo de 7 dias para o grupo de 28 dias (tabela 5.12 e figura 5.6).

Para comparação das quantidades de fibras, vasos e infiltrado inflamatório no tecido conjuntivo entre os lados controle e experimental, foi utilizado o teste não paramétrico de Wilcoxon para grupos pareados.

Com relação à quantidade de fibras do tecido conjuntivo, não foi evidenciada diferença estatisticamente significativa entre os lados experimentais e seus controles (tabela 5.13). 
TABELA 5.12 - Classificação microscópica da presença de seqüestros ósseos. Valores expressos em números absolutos de áreas observadas e separados por grupo e condição.

\begin{tabular}{cccc}
\hline \multirow{2}{*}{ Grupo } & Condição & \multicolumn{2}{c}{ Seqüestro ósseo } \\
& Presente $(\mathrm{n})$ & Ausente $(\mathrm{n})$ \\
\hline 1 & C & 0 & 10 \\
1 & DP & 6 & 4 \\
2 & C & 0 & 10 \\
2 & DP & 5 & 5 \\
3 & C & 0 & 10 \\
3 & DP & 1 & 9 \\
\hline
\end{tabular}

C - lado controle, DP - lado doença periodontal
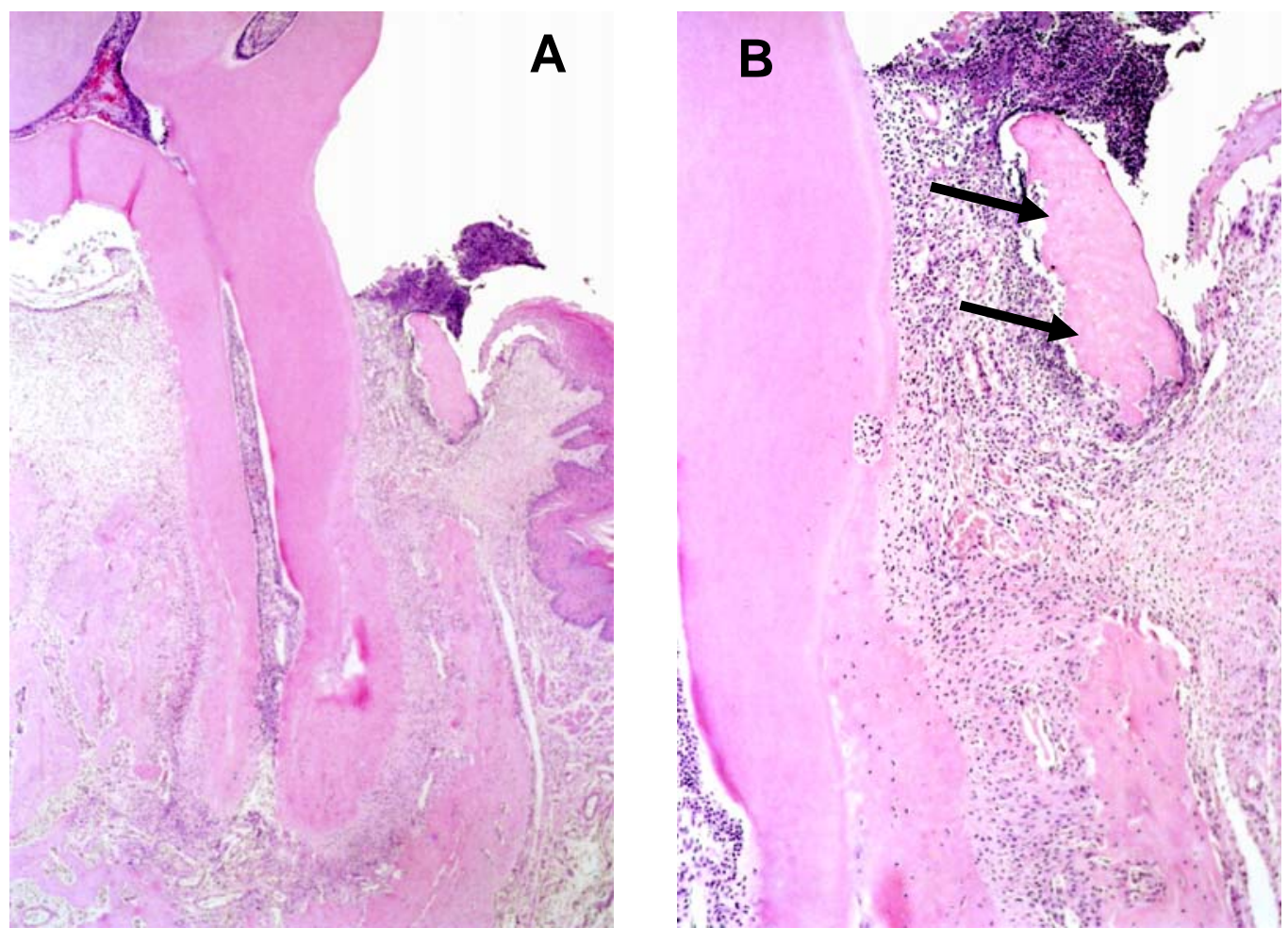

FIGURA 5.6: A: Seqüestro ósseo em sítio de doença periodontal de um rato do grupo de 7 dias. HE, 30x. B: Mesma região em aumento de 120x. Seqüestro ósseo indicado pelas setas. 
TABELA 5.13: Teste não-paramétrico de Wilcoxon para dois grupos pareados. Médias dos escores de avaliação da quantidade de fibras no tecido conjuntivo para os lados experimental e controle nos três grupos.

\begin{tabular}{cccc}
\hline Grupo & Condição & Média dos escores & p da diferença \\
\hline 1 & C & 2,10 & 0,785 \\
1 & DP & 2,06 & \\
2 & C & 2,28 & 0,246 \\
2 & DP & 2,10 & \\
3 & C & 2,06 & 0,211 \\
3 & DP & 2,30 & \\
\hline
\end{tabular}

C - lado controle; DP - lado doença periodontal

A quantidade de vasos sanguíneos no tecido conjuntivo foi maior no lado experimental que nos controles para os grupos de 7 e de 14 dias $(p=0,007$ e $p=0,01$, respectivamente). Para o grupo de 28 dias, também encontramos maior número de vasos no lado experimental, porém o resultado não foi estatisticamente significante (tabela 5.14 e figura 5.7).

A quantidade de infiltrado inflamatório foi sempre maior no lado experimental que no controle, os resultados foram estatisticamente significativos para os três grupos (tabela 5.15 e figuras 5.8 a 5.11).

O infiltrado inflamatório foi ainda dividido em quatro tipos: ausente, polimorfonuclear, mononuclear e misto. Os resultados mostraram que os lados controle não apresentavam infiltrado inflamatório e que este era principalmente polimorfonuclear nos grupos 1 e 2 e predominantemente mononuclear no grupo 3 (tabela 5.16 e figuras 5.12 e 5.13 ) 
TABELA 5.14: Teste não-paramétrico de Wilcoxon para dois grupos pareados. Médias dos escores de avaliação da quantidade de vasos sangüíneos no tecido conjuntivo para os lados experimental e controle nos três grupos.

\begin{tabular}{cccc}
\hline Grupo & Condição & Média dos escores & p da diferença \\
\hline 1 & C & 1,94 & $0,007^{*}$ \\
1 & DP & 2,46 & \\
2 & C & 1,74 & $0,014^{*}$ \\
2 & DP & 2,34 & \\
3 & C & 2,02 & 0,095 \\
3 & DP & 2,22 & \\
\hline
\end{tabular}

C - lado controle; DP - lado doença periodontal

* - resultado estatisticamente significante

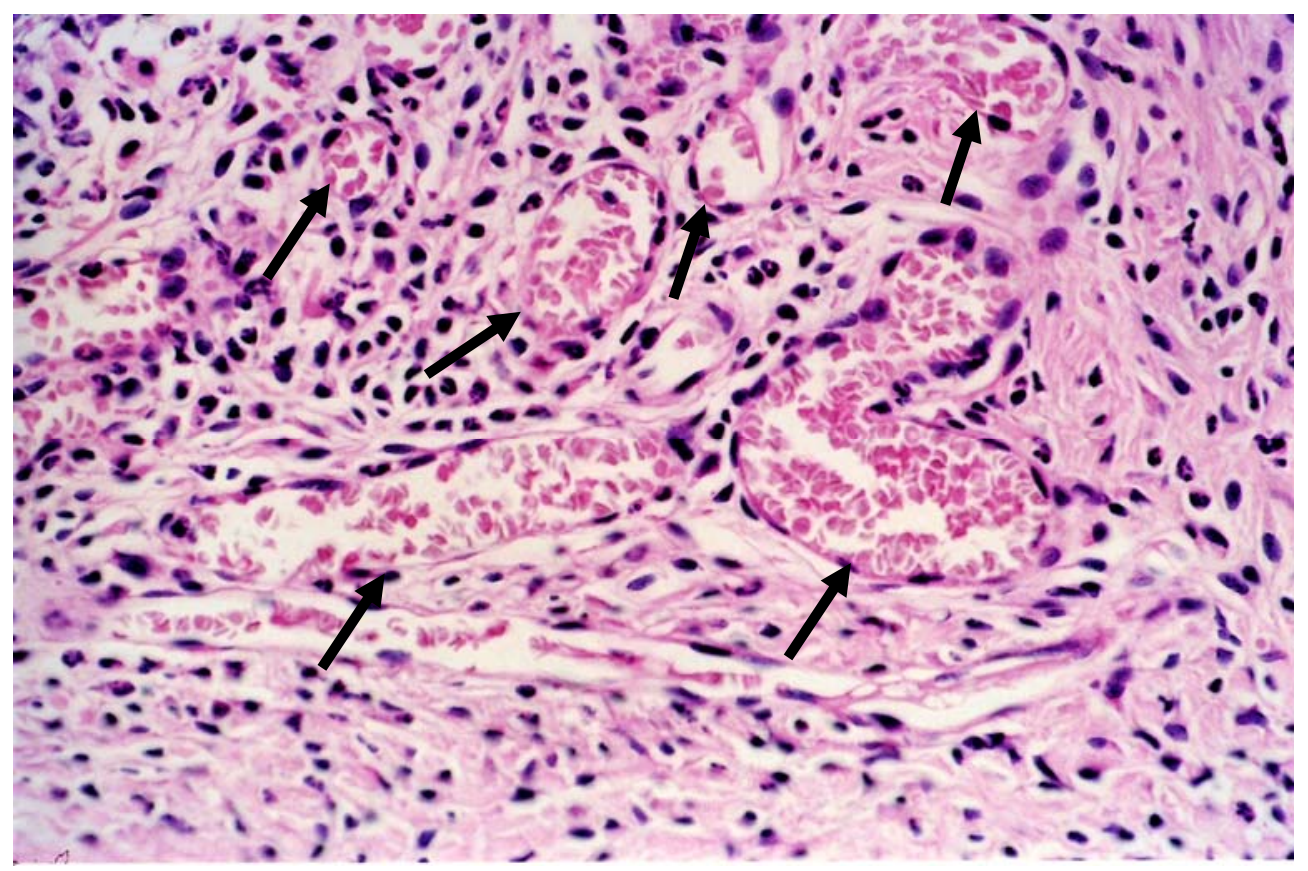

FIGURA 5.7: Intensa quantidade de vasos sangüíneos (setas) em sítio de doença periodontal em rato do grupo de 14 dias. HE, 475x. 
TABELA 5.15: Teste não-paramétrico de Wilcoxon para dois grupos pareados. Médias dos escores de avaliação da quantidade de infiltrado inflamatório no tecido conjuntivo para os lados experimental e controle nos três grupos.

\begin{tabular}{|c|c|c|c|}
\hline Grupo & Condição & Média dos escores & p da diferença \\
\hline 1 & $C$ & 0,14 & \multirow{2}{*}{$0,004^{*}$} \\
\hline 1 & DP & 2,62 & \\
\hline 2 & C & 0,10 & \multirow{2}{*}{$0,005^{*}$} \\
\hline 2 & DP & 2,30 & \\
\hline 3 & C & 0,06 & \multirow{2}{*}{$0,004^{*}$} \\
\hline 3 & DP & 1,46 & \\
\hline
\end{tabular}

TABELA 5.16 - Tipos microscópicos de infiltrado inflamatório, separados por grupo e condição. Valores expressos em números absolutos de áreas observadas e separados por grupo e condição.

\begin{tabular}{cccccc}
\hline Grupo & Condição & $\begin{array}{c}\text { Tusente } \\
\text { (n) }\end{array}$ & $\begin{array}{c}\text { Polimo de infiltrado inflamatório } \\
\text { (n) }\end{array}$ & $\begin{array}{c}\text { Misto } \\
\text { (n) }\end{array}$ & $\begin{array}{c}\text { Mononuclear } \\
\text { (n) }\end{array}$ \\
\hline 1 & C & 10 & 0 & 0 & 0 \\
1 & DP & 0 & 7 & 2 & 1 \\
2 & C & 9 & 1 & 0 & 0 \\
2 & DP & 0 & 8 & 2 & 0 \\
3 & C & 10 & 0 & 0 & 0 \\
3 & DP & 0 & 0 & 4 & 6 \\
\hline
\end{tabular}

C - lado controle, DP - lado doença periodontal 


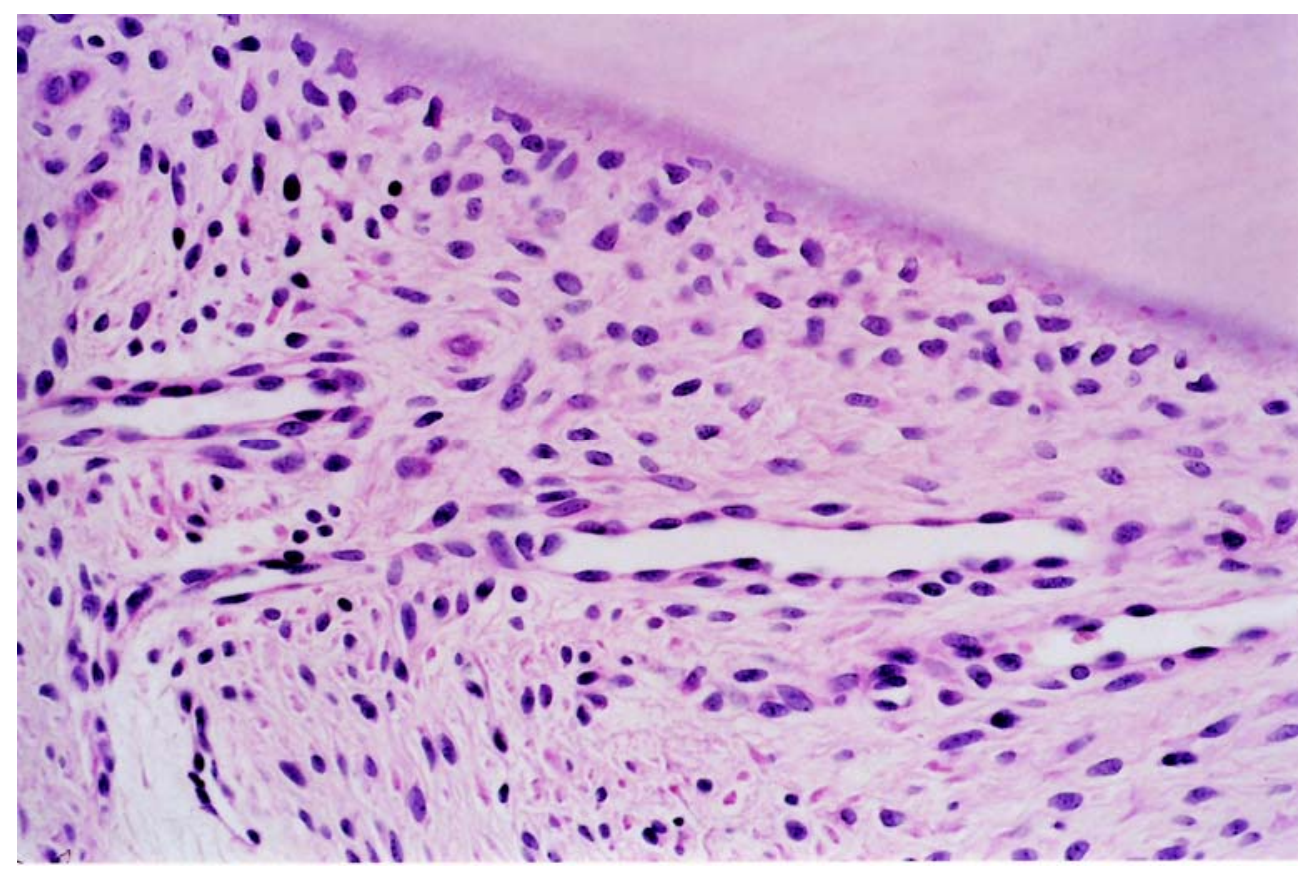

FIGURA 5.8: Ausência de infiltrado inflamatório no sítio controle de um rato do grupo 1. HE, 475x.

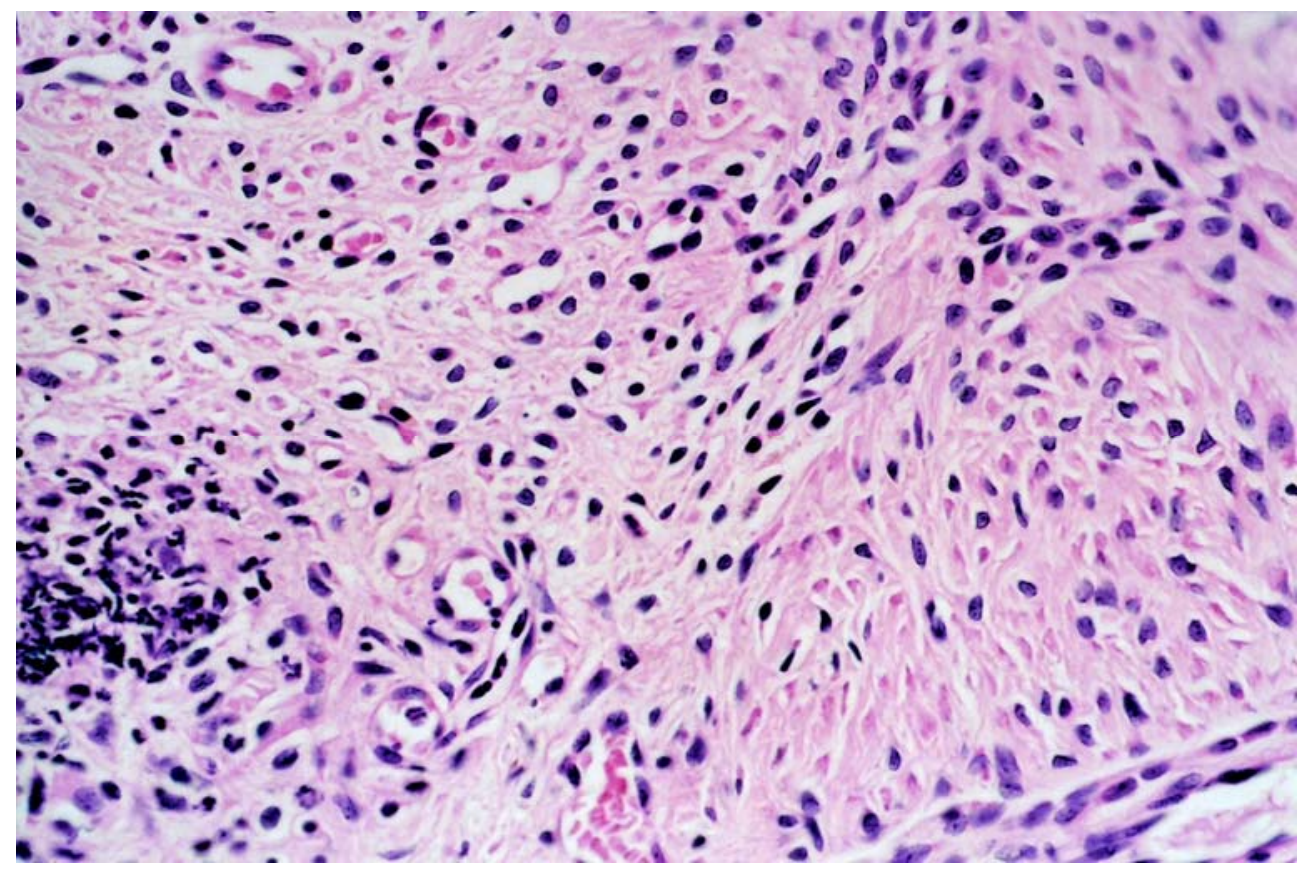

FIGURA 5.9: Infiltrado inflamatório leve em sítio de doença periodontal. HE, $475 x$. 


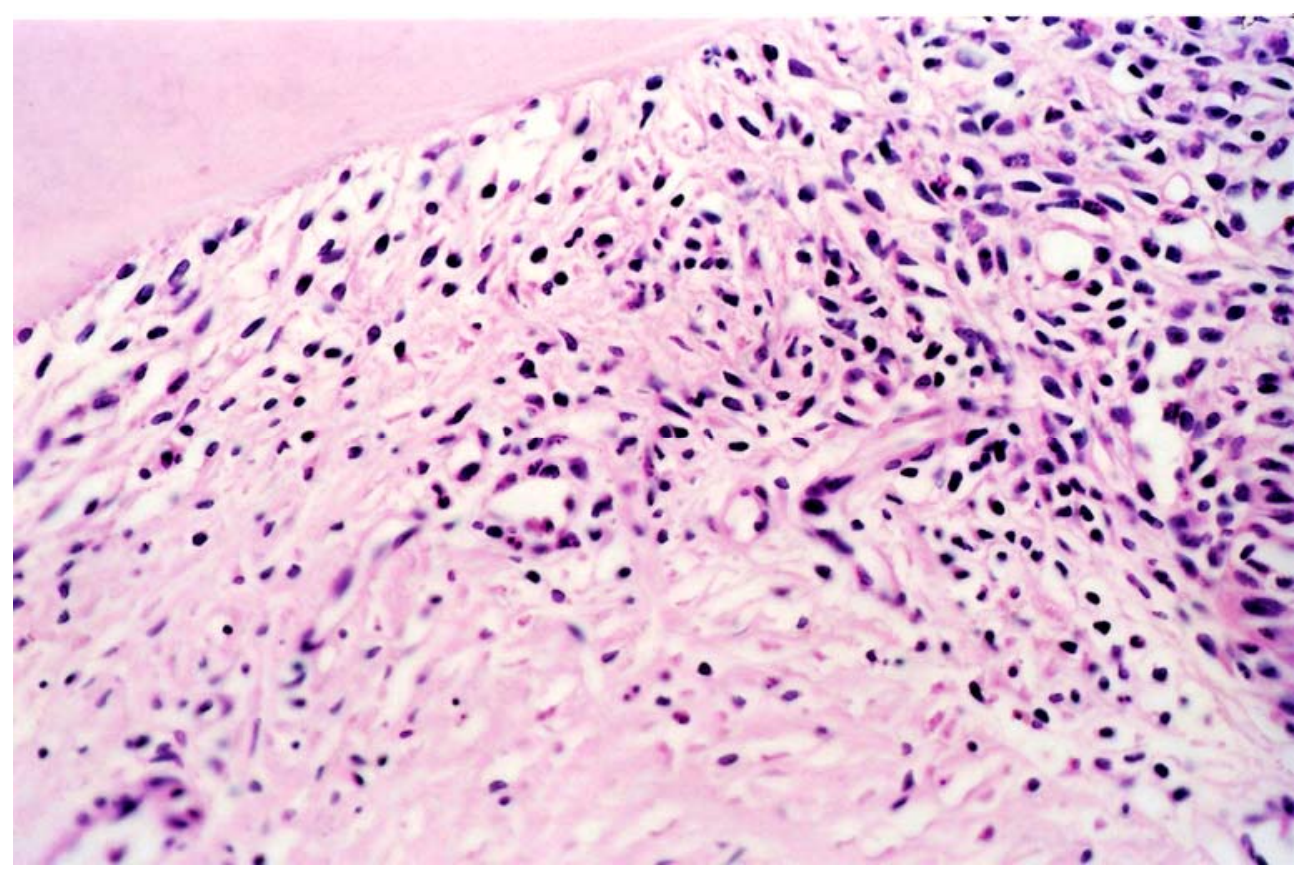

FIGURA 5.10: Infiltrado inflamatório moderado em área de doença periodontal. HE, 475x.

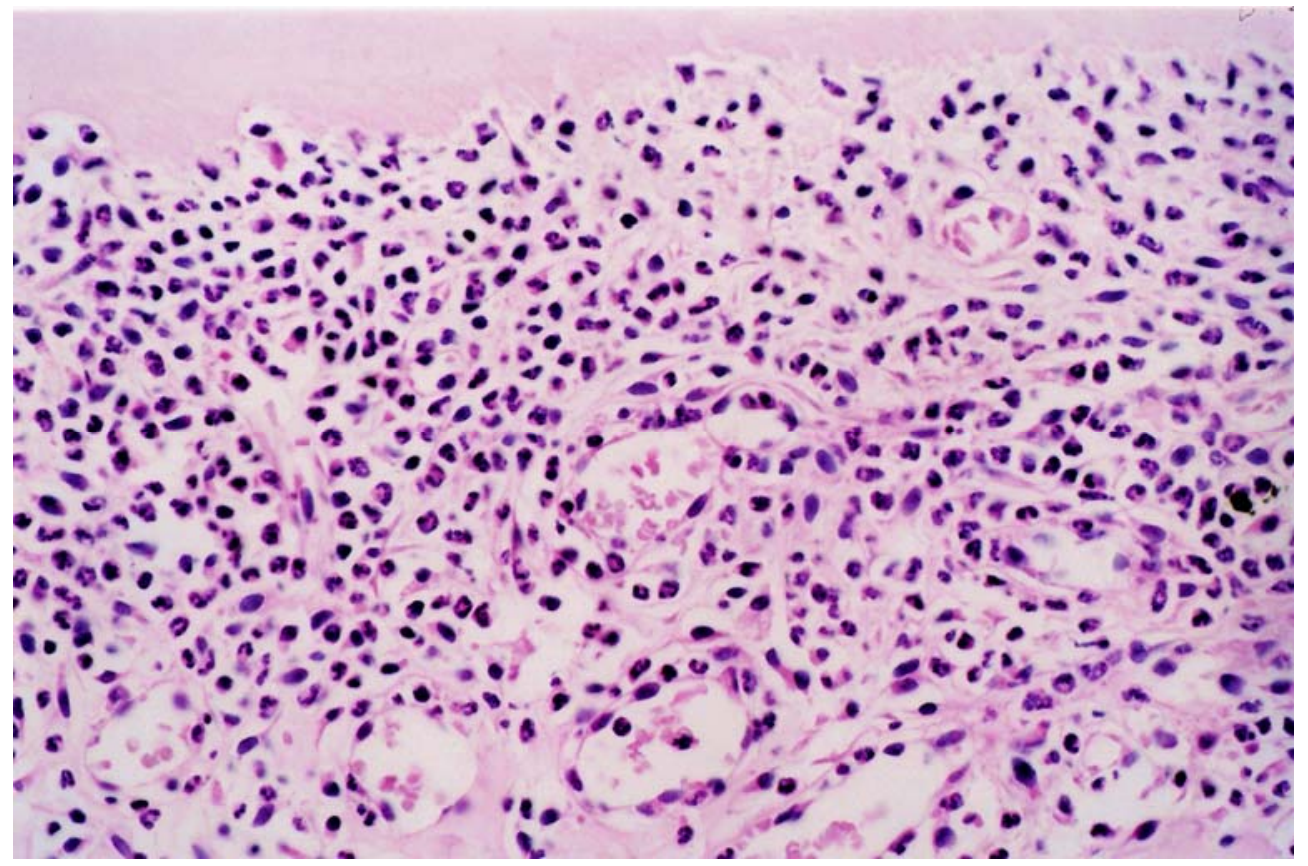

FIGURA 5.11: Infiltrado inflamatório intenso em área de doença periodontal. HE, 475x. 


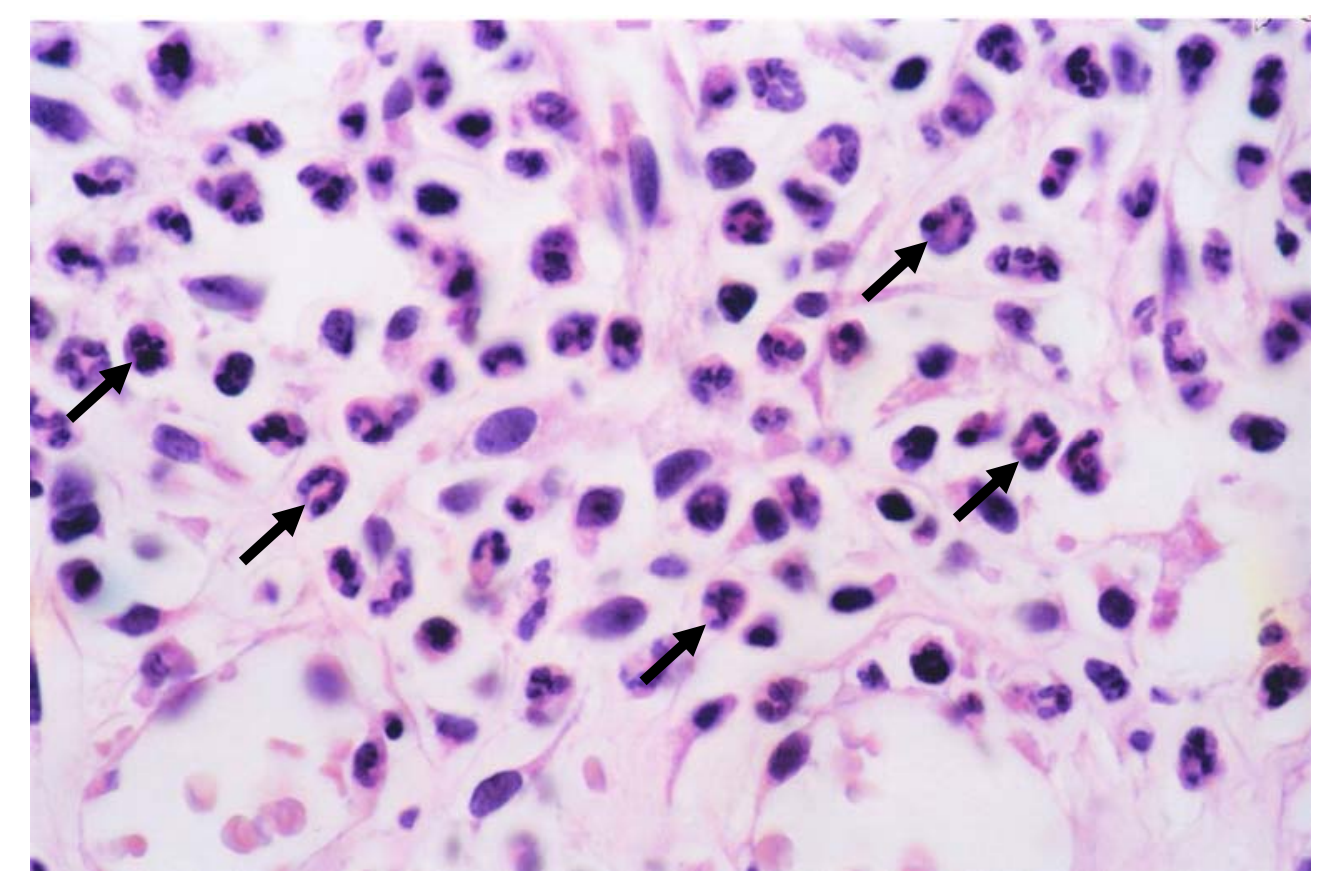

FIGURA 5.12: Infiltrado inflamatório intenso, composto predominantemente de células polimorfonucleares (setas). HE, 1190x.

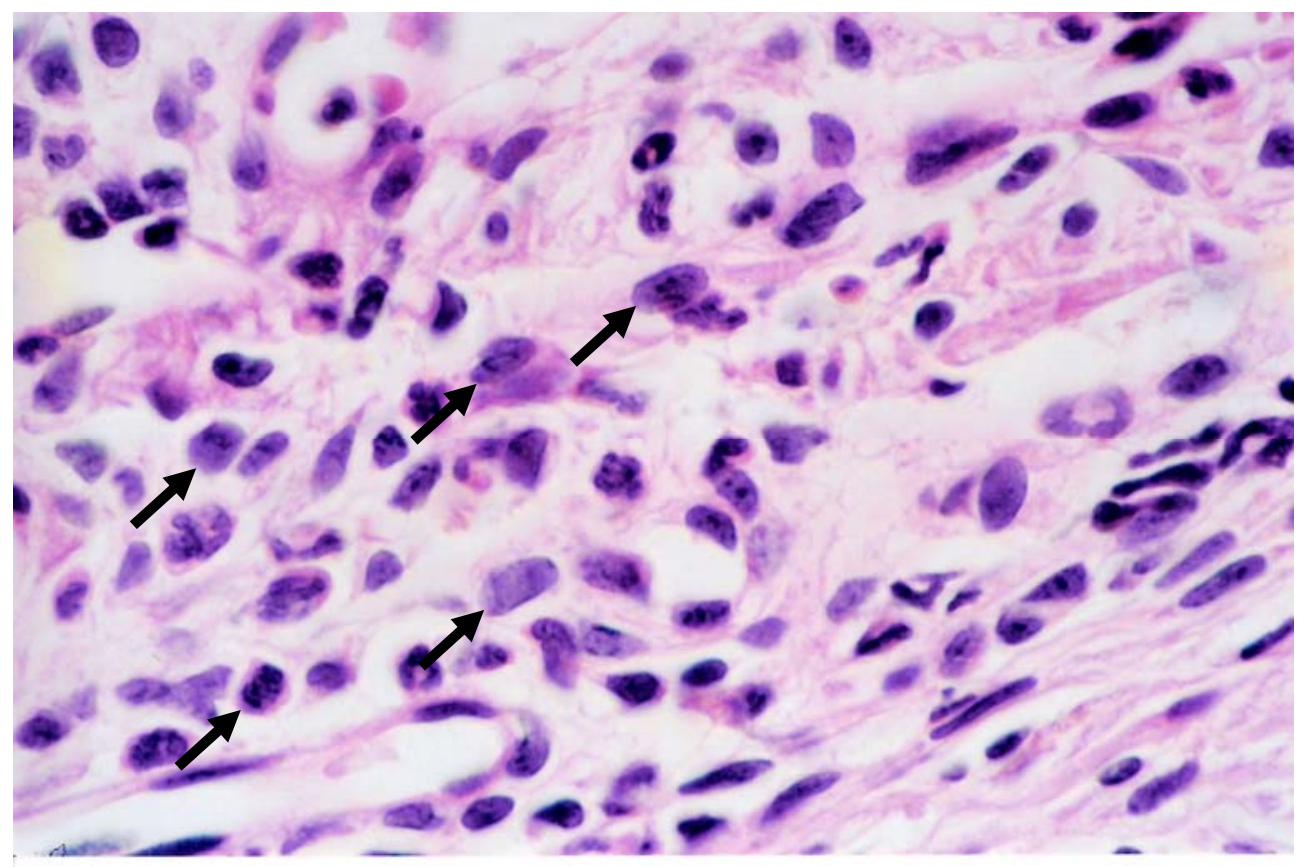

FIGURA 5.11: Infiltrado inflamatório composto por quantidade predominante de células mononucleares (setas). HE, 1190x 


\section{Discussão}




\section{DISCUSSÃO}

\subsection{Análise radiográfica}

Os resultados da mensuração do valor de pixel mostraram um padrão similar para todos os grupos, tanto para as imagens digitais obtidas no Digora, quanto para as digitalizadas pelo scanner a laser, no sentido de que os valores dos pixels das áreas de doença periodontal foram significantemente menores, do ponto de vista estatístico, que os valores das áreas de controle periodontal, indicando que o método foi eficaz em diferenciar áreas de perda óssea, mesmo para um período curto de 7 dias.

Alguns fatores externos poderiam interferir negativamente, alterando esses resultados, sendo o principal deles a inserção de ruído, proveniente da não-padronização das tomadas radiográficas, do processamento radiográfico, do escaneamento das radiografias convencionais e do erro de calibração do sistema Digora. A metodologia deste trabalho minimizou ao máximo essas interferências na qualidade das imagens obtidas. Para isso, a posição da fonte de raios- $x$ foi mantida estável durante todas as radiografias, 
todas as radiografias convencionais de cada grupo foram processadas em conjunto, a mesma placa de fósforo foi utilizada para todas as radiografias digitais diretas, o sistema Digora foi calibrado previamente e as radiografias convencionais de cada grupo foram escaneadas em conjunto no scanner a laser.

Mesmo com todos esses cuidados, foi ainda inserido em cada radiografia, um penetrômetro construído com lâminas de chumbo de películas radiográficas, para, se necessário, corrigir as imagens discrepantes. O uso desta ferramenta de correção é bem descrito na litaratura, mas os cálculos matemáticos de correção variam de um trabalho para o outro $9,26,33,64,65$. O valor de pixel foi medido neste penetrômetro para cada imagem, demonstrando bastante similaridade entre as radiografias de cada grupo, razão pela qual nenhum fator de correção baseado nessas medidas foi aplicado.

As medidas das áreas de doença periodontal e áreas de controle foram de fácil obtenção com a utilização do software ImageJ. A ferramenta de seleção de área deste programa permite manter o tamanho e forma da área selecionada totalmente padronizados, oferecendo maior confiabilidade ao método de medida. A padronização da área de medida logo abaixo da junção amelo-cementária foi apenas visual, o que não se tornou um problema para a padronização, pois os resultados mostraram um erro sistemático e erro casual pequenos entre duas medidas repetidas em intervalos de 15 dias. 
Os resultados obtidos para as medidas de valor de pixel nas áreas de doença periodontal evidenciaram ausência de diferenciação destes valores entre os grupos, demonstrando que a metodologia empregada não foi eficaz em avaliar diferenças de valor de pixel entre os períodos experimentais. Isto ocorreu nas comparações entre os grupos para as radiografias obtidas no sistema Digora (exceto grupos 2 e 3 ) e para as radiografias digitalizadas. Embora os sítios de doença periodontal do grupo 3 revelassem perda óssea histologicamente, a média dos valores dos pixels foi maior que a do grupo 2 . Essa inversão de grandeza de valor de pixel entre os grupos 3 e 2 não possui explicação histológica. Poderia ter ocorrido por adição de ruído ao exame de imagem porque o mesmo não ocorreu com a radiografia convencional.

O crescimento fisiológico dos animais poderia ter influenciado os resultados no lado controle, uma vez que houve diferença estatisticamente significante entre os grupos 1 e 3 (nas radiografias obtidas no Digora e nas radiografias digitalizadas) e entre os grupos 2 e 3 (nas radiografais do Digora apenas). O quanto o crescimento dos animais afetou os resultados no lado doente não é fácil de deduzir, uma vez que histologicamente havia perda óssea.

A comparação destes resultados com os resultados de outros trabalhos publicados é dificultada pelas grandes diferenças metodológicas. Poucos estudos em animais, com metodologia semelhante, foram publicados em literatura inglesa, nenhum deles avaliou doença periodontal. 
YOSHUIRA, OHKI, YAMADA ${ }^{78}$, em 1990, encorajaram o estudo do valor de pixel como método de quantificação radiográfica. Seus resultados de avaliação de histograma em sialografias de ratos mostraram diferenças entre os grupos com sialoadenite aguda e seus controles, com os padrões de histograma correlacionando-se com as diferenças microscópicas. Este estudo, da mesma forma que o trabalho realizado, foi capaz de evidenciar alteração do valor de pixel de áreas doentes, quando comparadas aos seus controles.

Mais recentemente, no ano de 2000, SARMENTO ${ }^{57}$ avaliou alterações periapicais em dentes de rato com pulpite, mostrando haver diferença no valor de pixel entre os grupos experimentais e seus controles. Demonstrou que, em dentes com pulpite, já se pode ter alterações no periápice, nem sempre observadas da maneira convencional. Este estudo foi bastante importante por encontrar alteração do valor de pixel em áreas onde alterações visuais não são notadas habitualmente. A metodologia empregada por SARMENTO ${ }^{57}$ serviu como base para o desenvolvimento da metodologia deste trabalho, o que torna possivel estabelecer um paralelo entre os dois estudos, reforçando que, do ponto de vista experimental, a avaliação do valor de pixel teria importância diagnóstica na Odontologia, em duas grandes áreas de interesse: Endodontia e Periodontia, devendo ser levado em consideração o fator padronização da imagem, bem empregado neste trabalho e por SARMENTO ${ }^{57}$ em 2000. 
O trabalho desenvolvido por DELANO et al. ${ }^{15}$, em 1998 foi eficaz em encontrar concordância entre a histopatologia da doença periapical e seu valor de pixel medido em radiografias digitais. Induziram e trataram lesões periapicais em cachorros beagle, obtiveram radiografias padronizadas e a forma de análise microscópica foi por meio de morfometria das áreas de lesão. Demonstraram que a medida de densidade por valor de pixel é um bom indicador de cicatrização de patologias apicais, podendo ser utilizado no acompanhamento destas lesões. Estes resultados diferem dos encontrados neste trabalho, pois foi possível evidenciar alteração do valor de pixel com o passar do tempo. Por ter trabalhado com cachorros, foi possível fazer radiografias iniciais e de acompanhamento bem padronizadas no mesmo animal, o que não seria viável em um estudo com ratos, pelas próprias limitações de tamanho.

Extrapolar os resultados obtidos em modelos animais para humanos pode ser especialmente difícil pelas dificuldades na obtenção de um bom padrão-ouro, pois a análise microscópica de tecidos humanos sadios é difícil de ser obtida por causa de limitações éticas. No intuito de comprovar experimentalmente que a avaliação do valor de pixel indica perda mineral em mandíbulas humanas, SHROUT et al. ${ }^{62}$, em 2003 e JETT et al. ${ }^{33}$, em 2004 publicaram trabalhos semelhantes, onde removeram osso medular de fragmentos de mandíbulas de cadáveres e radiografaram as peças para medir o valor de pixel das áreas de osso removido. Ambos comprovaram, com essa metodologia, que foi possível detectar perda de osso medular e cortical, mesmo quando essa perda não era ainda visível. 
Algumas pesquisas in vivo em humanos publicadas até o momento são baseadas em radiografias de arquivo ${ }^{58,60,63,75}$. Mesmo que os resultados tenham demonstrado eficácia da medida do valor de pixel, restam dúvidas sobre a acurácia do método, por não haver, nesses estudos, um padrão-ouro confiável. Radiografias de arquivo podem apresentar uma série de erros inerentes à sua obtenção e processamento químico, assim como a falta de padronização de posicionamento.

Outros trabalhos em humanos utilizaram radiografias padronizadas na avaliação do valor de pixel em lesões periapicais. Para tal, utilizaram como padrão-ouro o índice periapical desenvolvido por ØRSTAVIK, KEREKES, ERIKSEN $^{52}$, em $1986^{9}$, 16, 18, 38, 51 . Como esse índice foi previamente validado por meio de análise microscópica, poderia funcionar como um bom padrão de comparação. Esses trabalhos obtiveram resultados que confirmam a similaridade entre o índice periapical e a medida do valor de pixel. CAMPS, POMMEL, BUKIET ${ }^{9}$ mostraram, em 2004, que é possível evidenciar alterações ósseas em lesões periapicais pela medida de valor de pixel entre a radiografia inicial e seus controles, mesmo quando o índice periapical não sofre mudança.

Entre as muitas áreas de utilização do valor de pixel em Odontologia existentes na literatura, parece ser a Periodontia a menos estudada, talvez pelas dificuldades de obtenção de um padrão-ouro adequado. Em periodontia, o padrão ideal para pesquisa em humanos seria a realização das medidas do nível ósseo depois de rebatido um retalho e com total 
visualização da crista alveolar ${ }^{19}, 40$. No entanto, as implicações éticas desta prática não permitem que isto seja realizado rotineiramente. Por esse motivo, poderia ser aceito como padrão-ouro a medida de profundidade de sondagem e nível de inserção clínica sob anestesia local ${ }^{19,77}$.

O tempo de monitoramento da doença periodontal seria outro fator que dificultaria os estudos em periodontia. Em um trabalho com acompanhamento de 1 ano, a correlação foi 0,07 entre medidas radiográficas lineares da JAC à crista alveolar e nível de inserção clínica ${ }^{29,}$ ${ }^{44}$, enquanto o acompanhamento de 10 anos mostrou correlação de $0,8^{54}$, demonstrando que quanto maior o tempo de acompanhamento maior a relação entre análise radiográfica e nível de inserção clínica.

Os resultados encontrados neste trabalho indicaram uma similaridade entre os dados obtidos para as radiografias do sistema Digora e radiografias digitalizadas. Isto indicaria que o valor de pixel poderia ser eficaz em distinguir alterações entre áreas saudáveis e com perda óssea, mas a metodologia empregada não foi capaz de evidenciar diferenças nos valores dos pixels entre os diferentes períodos da doença instalada.

Os resultados da concordância intra-examinador mostraram diferença estatisticamente significante entre as primeiras medidas e as medidas subseqüentes. Esta diferença foi muito pequena e possivelmente detectada porque o teste matemático empregado é muito robusto e o valor de pixel muito exato. Dificilmente os valores seriam exatamente iguais nas duas medidas. Por estes motivos, foi possível considerar que a ausência de 
concordância intra-examinador seria insignificante do ponto de vista prático, pela pequena magnitude das diferenças encontradas nos valores dos pixels entre as duas medidas subseqüentes.

\subsection{Análise histopatológica}

Os roedores são amplamente utilizados nos estudos de doença periodontal pelo baixo custo e facilidade de manejo, assim como pela grande semelhança tecidual e de respostas periodontais com os humanos ${ }^{32,37,72}$.

A forma de indução de doença periodontal utilizada neste trabalho foi bastante empregada na literatura. Em todos os casos onde a colocação da ligadura esteve associada à placa bacteriana, houve indução de doença em vários graus de severidade, podendo haver perda óssea dependendo do tempo experimental e do tipo de ligadura e de animal empregados ${ }^{1,10,11,23,}$ $24,25,34,36,37,42,43,48,49,72$

No trabalho apresentado, a metodologia foi capaz de induzir inflamação e perda óssea nos tecidos periodontais com o uso de ligadura de seda 3-0, na região mesial do primeiro molar inferior do lado direito. A perda óssea foi visível microscopicamente a nos três grupos e houve um padrão de diminuição da altura da crista óssea alveolar com o passar do tempo. 
Os resultados deste trabalho mostraram aumento da severidade da perda óssea com o passar do tempo, no entanto, houve diminuição do infiltrado inflamatório, com cronificação da resposta inflamatória no grupo de 28 dias. KUHR et al. ${ }^{43}$, em 2004, avaliou a destruição dos tecidos periodontais em ratos por um período de 60 dias, induzindo doença com ligadura de seda 5-0 no segundo molar superior. Estes resultados evidenciaram uma redução no efeito da ligadura de seda sobre os tecidos com o passar do tempo, devido ao processo de remodelação óssea. Outros trabalhos com diferentes espécies animais concordam com esta afirmação, ao encontrar como resultados uma diminuição do potencial de reabsorção óssea com o passar do tempo, sugerindo um rápido processo inflamatório agudo inicial, que declina posteriormente $\mathrm{e}^{1,36,49}$.

A menor presença de osteoclastos e lacunas de Howship aos 28 dias indicam uma diminuição do processo de remodelação óssea, conforme observado por NYMAN, SCHROEDER, LINDHE ${ }^{49}$, em 1979, em cachorros beagle, no mesmo período experimental.

A presença de seqüestros ósseos neste trabalho, principalmente aos 7 e 14 dias, foi também evidenciada no experimento de JOHNSON ${ }^{34}$, em 1975, no qual foi utilizada ligadura de seda em ratos albinos por no mínimo 17 dias. GALVÃO et al. ${ }^{23}$, em 2003, evidenciaram em sua amostra, presença de seqüestros ósseos em ratos Wistar com ligaduras de algodão mantidas por 30 dias no segundo molar superior. 
A quantidade de fibras no tecido conjuntivo periodontal foi avaliada neste trabalho, não sendo encontrada diferença significante entre o lado doença periodontal e controle para nenhum dos períodos experimentais. Galvão et al, 2003 relatou perda de fibras acima da crista óssea alveolar em áreas de doença periodontal induzida. ROVIN, COSTICH, GORDON ${ }^{55}$, em 1966, evidenciaram aumento da proliferação e atividade de fibroblastos após 2 e 4 semanas de indução de doença.

A evolução da resposta inflamatória encontrada neste trabalho foi bastante semelhante aos relatos da literatura. Foi evidenciada maior quantidade de infiltrado inflamatório nos lados experimentais, quando comparados aos seus controles, para todos os grupos, assim como a quantidade de vasos sangüíneos para os períodos de 7 e 14 dias. GASPERSIC, STIBLAR-MARTINCIC, SKALERIC ${ }^{24}$, em 2002, ao induzir doença periodontal em ratos Wistar com fio de seda 4-0 por 4 semanas, encontraram marcante vasodilatação e infiltrado inflamatório. O infiltrado era predominantemente composto por células mononucleares, com poucos polimorfonucleares, indicando uma reação crônica. Abundância de vasos sangüíneos foi relatada por GALVÃO et al. ${ }^{23}, 2003$, em período experimental de 30 dias. Vasodilatação e aumento de infiltrado inflamatório foram encontrados por KENWORTHY, BAVEREL ${ }^{37}$, em 1981, após 15 semanas de indução de doença periodontal com fio de seda.

Os dentes que não receberam fio de seda (dentes sem ligadura) mostraram, neste trabalho, ausência de sinais inflamatórios e de reabsorção 
óssea na crista alveolar. A ausência de sinais inflamatórios em dentes sem ligadura foi descrita por NOCITI Jr et al. ${ }^{48}$, em 2000 e por AMSTAD-JOSSI, $\mathrm{SCHROEDER}^{2}$, em 1978. Estes últimos mostraram ainda que o tecido conjuntivo apresenta densa quantidade de fibras colágenas. Com relação à reabsorção óssea em dentes de ratos sem ligadura, estudos comprovam uma ação reabsortiva relacionada à idade ${ }^{2,43}$. Há aumento da distância entre a JAC e o topo da crista óssea com o passar do tempo na região lingual do primeiro molar inferior. KUHR et al. ${ }^{43}$, em 2004, mostraram perda óssea fisiológica em ratos avaliados por um período curto, de 60 dias, utilizando uma ferramenta de análise sensível que mediu a perda óssea em décimos de milímetros. Um achado semelhante a este, de perda óssea fisiológica, não foi evidenciado neste trabalho, provavelmente pelo curto período experimental, pelo fato de os cortes microscópicos terem sido posicionados na região mais central do alvéolo dentário e por não ser utilizada uma ferramenta de medida objetiva da altura da crista óssea.

Em resumo, a metodologia de indução de doença periodontal empregada foi eficaz em produzir perda óssea na crista alveolar e a análise histopatológica empregada evidenciou um padrão de doença periodontal descrito anteriormente e semelhante ao encontrado em humanos. Por meio desta metodologia, foi possível avaliar a perda óssea na crista alveolar e comprovar que a alteração radiográfica medida por meio do valor de pixel da imagem foi condizente com as diferenças histopatológicas entre as áreas de doença periodontal e seus controles. 


\subsection{Novas pesquisas}

Pesquisas futuras são necessárias para validar clinicamente o uso do valor de pixel como ferramenta diagnóstica. Há evidências experimentais suficientes, baseadas em estudos em animais, de que esta ferramenta mereça ser melhor pesquisada em humanos.

Um estudo de valor de pixel em doença periodontal em humanos deveria ser prospectivo, com radiografias iniciais e controles seguindo um mesmo padrão, com radiografias digitais diretas ou convencionais bem padronizadas, e com pacientes que necessitassem de cirurgia periodontal, uma maneira de propiciar o acesso direto à crista óssea alveolar para realizar medições.

A eliminação de variáveis externas nestes trabalhos é extremamente importante, mas difícil de ser obtida. A inserção de ruído é um dos principais fatores que interfere negativamente nos resultados dos trabalhos que avaliam densidade óssea por meio de radiografias. Portanto, seria importante minimizar alterações de posicionamento, de processamento radiográfico, de escaneamento e avaliar previamente, sempre que possível, se o sistema digital utilizado possui algum erro inerente ao processo de digitalização. 


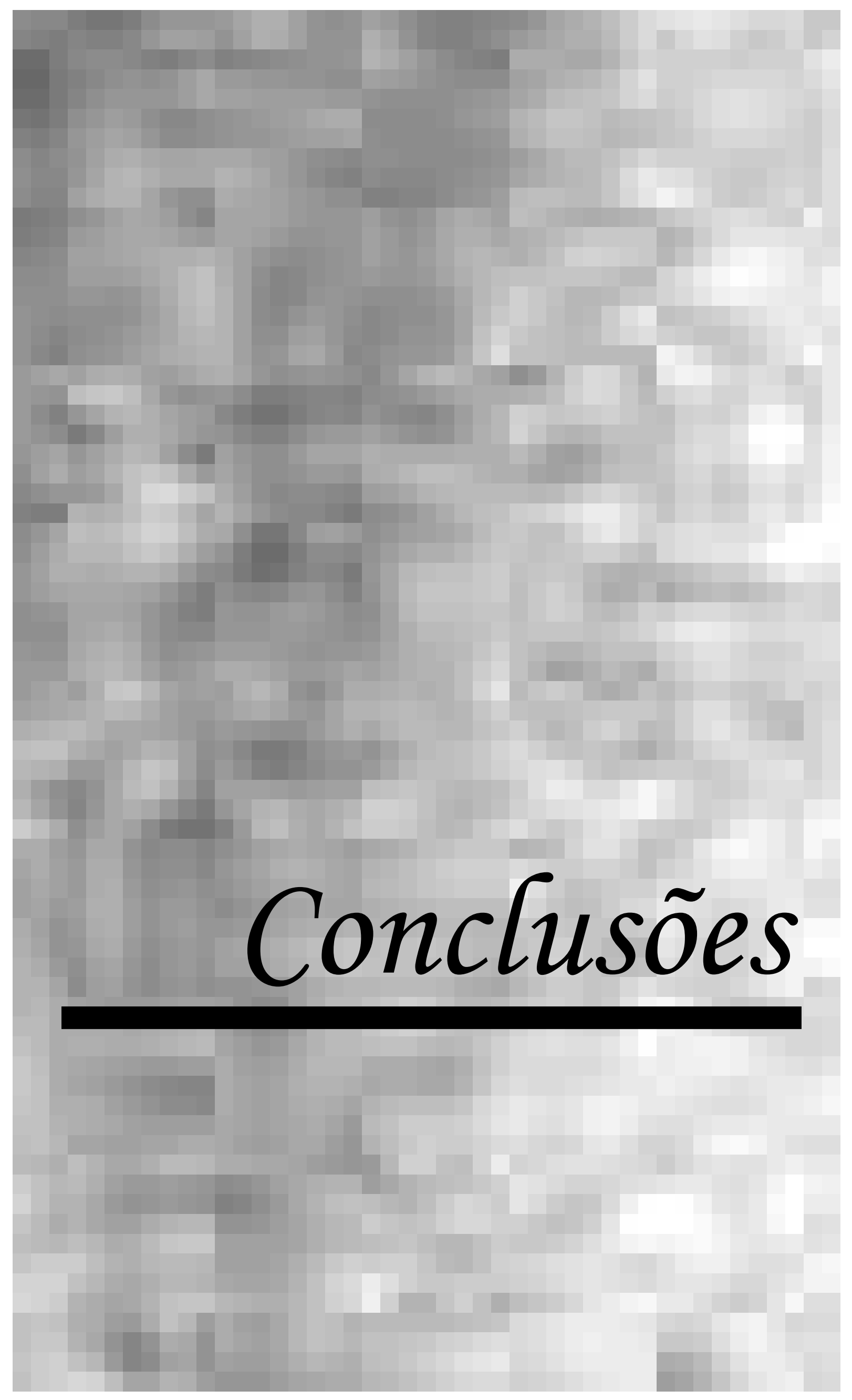




\section{CONCLUSÕES}

Baseando-se na proposição e nas limitações da metodologia empregada, foi possível concluir, por meio deste trabalho, que:

1. Os valores dos pixels dos sítios de doença periodontal experimentalmente induzida em ratos Wistar foram menores que os valores dos sítios de controle, para os 3 grupos estudados em ambos os métodos: radiografia convencional digitalizada e radiografia digital obtida no sistema Digora.

2. A altura da crista óssea avaliada histologicamente foi menor para os sítios de doença periodontal que para os sítios controles, comprovando a perda óssea das áreas de doença em relação aos seus controles.

3. Não foi possível detectar diminuição dos valores dos pixels conforme o período experimental aumentou, a despeito de ter sido possível evidenciar histologicamente a diminuição da altura da crista óssea com o aumento do tempo experimental. 


\title{
ANEXOS
}

ANEXO 1

\author{
Universidade de São Paulo \\ Faculdade de Odontologia de Bauru \\ Al. Dr. Octávio Pinheiro Brisolla, 9-75 - Bauru-SP - CEP 17012-901 - C.P. 73 \\ PABX (0XX14)235-8000 - FAX (0XX14)223-4679 \\ Comissäo de Éfica no Ensino e Pesquisa em Animais
}

CEEPA-Proc. $N^{\circ} 01 / 2004$

Bauru, 05 de fevereiro de 2004

Senhora Professora,

O projeto de pesquisa encaminhado a esta Comissão de Ética no Ensino e Pesquisa em Animais, denominado "Avaliação de reabsorção óssea periodontal comparando os valores de pixels com análise histopatológica - estudo experimental em ratos", de autoria de Ligia Buloto Schmitd, a ser desenvolvido sob sua orientação, foi enviado ao relator para avaliação.

Na reunião de 04 de fevereiro de 2004 esta Comissão aprovou o parecer do relator, considerando que não existem infrações éticas.

Atenciosamente,

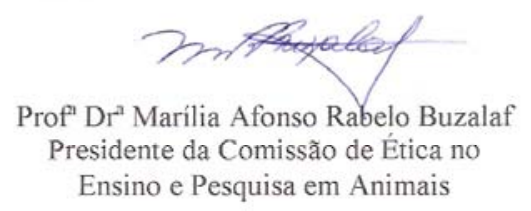

$\mathrm{Ilm}^{\mathrm{a}} \mathrm{Sr}^{-3}$ Prof" Dra Izabel Regina Fischer Rubira-Bullen

DD. Docente do Departamento de Estomatologia 


$$
\begin{aligned}
& \text { Referências } \\
& \text { Bibliográficas }
\end{aligned}
$$




\section{REFERÊNCIAS BIBLIOGRÁFICAS *}

1. ADAMS, R.A.; ZANDER, H.A.; POLSON, A.M. Cell populations in the trasseptal fiber region before, during and after experimental periodontitis in squirrel monkeys. J Periodontol, v.50, n.1, p.7-12, Jan. 1979.

2. AMSTAD-JOSSI, M; SCHROEDER, H.E. Age-related alterations of periodontal structures around cementoenamel junction and of the gingival connective tissue composition in germfree rats. J Periodont Res, v.13, n.1, p.76-90, Jan. 1978.

3. ANALOUI, M. Radiographic image enhancement. Part I: special domain techniques. Dentomaxillofac Radiol, v.30, n.1, p.1-9, Jan. 2001.

4. ARAKI, K.; ENDO, A.; OKANO, T. An objective comparison of four digital intra-oral radiographic systems: sensitometric properties and resolution. Dentomaxillofac Radiol, v.29, n.2, p.76-80, Mar. 2000.

* NBR 10719 (Associação Brasileira de Normas Técnicas)

Normas recomendadas para uso no âmbito da Universidade de São Paulo,com base no documento "Referência Bibliográficas e Exemplos", emanados do Conselho Supervisor do Sistema integrado de bibliotecas da USP, em reunião de 20 de setembro de 1990. 
5. BENDER, I.B.; SELTZER, S. Roentgenographic and direct observation of experimental lesions in bone, I. J Amer Dent Assoc, v.62, p.152-60, 1961.

6. BENDER, I.B.; SELTZER, S. Roentgenographic and direct observation of experimental lesions in bone, II. J Amer Dent Assoc, v.62, p.708-16, 1961

7. BRÄGGER, D. et al. Computer-assisted densitometric image analysis in periodontal radiography. A methodological study. J Clin Periodontol, v.15, n.1, p.27-37, Jan. 1988.

8. BRÄGGER, U. et al. Computer-assisted densitometric image analysis of digital subtraction images: in vivo error of the method and effect of thresholding. J Periodontol, v.69, n.9, p.967-74, Sept. 1998.

9. CAMPS, J.; POMMEL, L.; BUKIET, F. Evaluation of periapical lesion healing by correction of gray values. J Endod, v.30, n.11, p.762-6, Nov. 2004.

10. CARRANZA, F.A. et al. Histometric evaluation of periodontal bone loss in rats. J Periodontal Res, v.6, n.1, p.65-72, 1971.

11. CARRANZA, F.A.; SIMES, R.J.; CABRINI, R.L. Effect of combined etiological factors in experimental periodontal lesions. J Periodontal Res, v.4, Supp 4, p.33-34, 1969.

12.COSTISH, E.R; AVERY, J.K.; HOEK, R.B. Armamentarium for transplantation of teeth in hamsters. J Oral Surg Anesth, v.20, p.3259, 1962. 
13.DAMANTE, J.H.; CARVALHO, P.V. Contribuição à interpretação radiográfica de lesões ósseas produzidas experimentalmente em mandíbulas humanas secas (Parte I). Rev Odontol USP, v.2, n.3, p.131-8, jul./set. 1988.

14.DAVIDSON, H.C. et al. Comparison of radiographic image quality from four digitization devices as viewed on computer monitors. J Digit Imaging, v.14, n.1, p.24-9, Mar. 2001.

15.DELANO, E.O. et al. Quantitative radiographic follow-up of apical surgery: a radiometric and histologic correlation. J Endod, v.24, n.6, p.420-6, June 1998.

16. DELANO, E.O. et al. Comparison between PAI and quantitative digital radiographic assessment of apical healing after endodontic treatment. Oral Surg Oral Med Oral Pathol Oral Radiol Endod, v.92, n.1, p.108-15, July 2001.

17. DIGORA OPTIME TECHNICAL DATA. Disponível na Internet. http://www.soredex.com , 30 mar. 2005.

18. DUBREZ, B. et al. Comparison of photodensitometric with high-resolution digital analysis of bone density from serial dental radiographs. Dentomaxillofac Radiol, v.21, n.1, p.40-4, Feb. 1992.

19. EICKHOLZ, P.; HAUSMANN, E. Evidence for healing of periodontal defects 5 years after conventional and regenerative therapy: digital subtraction and bone level measurements. J Clin Periodontol, v.29, n.10, p.922-8, Oct. 2002. 
20. ESCARPINATI, M.C.; VIEIRA, M.A.; SCHIABEL, H. Computer technique for digital radiographic images correction based on the digitizer characteristic curve. J Digit Imaging, v.15, Suppl 1, p.228-30, 2002.

21.FARMAN, A.G.; SCARFE, W.C. Pixel perception and voxel vision: constructs for a new paradigm in maxillofacial imaging. Dentomaxillofac Radiol, v.23, n.1, p.5-9, Feb. 1994.

22. FULTON, W. A few scanning tips. 6.ed. Wayne Fulton, editor. USA, 2004.

23. GALVÃO, M.P. de A. et al. Methodological considerations on descriptive studies of induced periodontal diseases in rats. Pesqui Odontol Bras, v.17, n.1, p.56-62, jan./mar. 2003.

24. GASPERSIC, R.; STIBLAR-MARTINCIC, D.; SKALERIC, U. Influence of restraint stress on ligature-induced periodontitis in rats. Eur J Oral Sci, v.110, n.2, p.125-9, Apr. 2002.

25. GONÇALVES, P.F. et al. Immunosuppressant therapy and bone loss in ligature-induced periodontitis - a study in rats. Pesqui Odontol Bras, v.17, n.1, p.46-50, jan./mar. 2003.

26. GÜRDAL, P.; AKDENIZ, B.G. Comparison of two methods for radiometric evaluation of resin-based restorative materials. Dentomaxillofac Radiol, v.27, n.4, p.236-9, July 1998.

27. HANGIANDEROU, N.J.; O'CONNOR, T.J.; FELMLEE, J.P. An evaluation of the signal and noise characteristics of four CCD-based film digitizers. Med Phys, v.25, n.10, p.2020-6, Oct. 1998. 
28. HAUSMANN, E. Radiographic and digital imaging in periodontal practice. J Periodontol, v.71, n.3, p.497-503, Mar. 2000.

29. HAUSMANN, E. et al. Studies on the relationship between changes in radiographic bone height and probing attachment. J Clin Periodontol, v.21, n.2, p.128-32, Feb. 1994.

30. HAYAKAWA, $Y$ et al. Intraoral radiographic storage phosphor image mean pixel values and signal to noise ratio. Oral Surg Oral Med Oral Pathol Oral Radiol Endod, v.86, n.5, p.601-5, Nov. 1998.

31. HOUSTON, W.J. The analysis of errors in orthodontic measurements. Am J Orthod, v.83, n.5, p.382-90, May 1983.

32. IRVING, J.T.; SOCRANSKY, S.S.; HEELEY, J.D. Histological changes in experimental periodontal disease in gnobiotic rats and conventional hamsters. J Periodontal Res, v.9, n.2, p.73-80, 1974.

33. JETT, S. et al. An evaluation of the origin of trabecular bone patterns using visual and digital image analysis. Oral Surg Oral Med Oral Pathol Oral Radiol Endod, v.98, n.5, p.598-604, Nov. 2004.

34.JOHNSON, I.H. Effects of local irritation and dextran sulphate administration on the periodontum of the rat. J Periodontal Res, v.10, n.6, p.332-45, Dec. 1975.

35. KASHIMA, I. Computed radiography with photostimulable phosphor in oral and maxillofacial radiology. Oral Surg Oral Med Oral Pathol Oral Radiol Endod, v.80, n.5, p.577-89, Nov. 1995.

36.KENNEDY, J.E.; POLSON. A.M. Experimental marginal periodontitis in squirrel monkeys. J Periodontol, v. 44, n.3, p.140-4, Mar. 1973. 
37. KENWORTHY, R.; BAVEREL, M. Studies of a periodontal tissue lesion in the rat, untreated or treated with chlorhexidine digluconate. J Clin Periodontol, v.8, n.4, p.349-58, Aug. 1981.

38.KEROSUO, E.; ØRSTAVIK, D. Application of computerized image analysis to monitoring endodontic therapy: reproducibility and comparison with visual assessment. Dentomaxillofac Radiol, v.26, n.2, p.79-84, Mar. 1997.

39. KHADEMI, J.A. Digital images \& sound. J Dent Educ, v.60, n.1, p.41-6, Jan. 1996.

40.KIM TS, BENN DK, EICKHOLZ P. Accuracy of computer-assisted radiographic measurements of interproximal bone loss in vertical bone defects. Oral Surg Oral Med Oral Pathol Oral Radiol Endod; v.94, n.3, p.379-87, Sept. 2002.

41. KLAUSEN, B. Microbiological and immunological aspects of experimental periodontal disease in rats: a review article. J Periodontol, v.62, n.1, p.59-73, Jan. 1991.

42. KOIDE, M. et al. In vivo administration of IL-1 $\beta$ accelerates silk ligatureinduced alveolar bone resorption in rats. J Oral Pathol Med, v.24, n.9, p.420-34, Oct. 1995.

43. KUHR, A. et al. Observations on experimental marginal periodontitis in rats. J Periodont Res, v.39, n.2, p.101-6, Apr. 2004.

44. MACHTEI, E.E. et al. The relationship between radiographic and clinical changes in the periodontium. J Periodont Res, v. 32, n.8, p.661-6, Nov. 1997. 
45.MOL A.; VAN der STELT, P.F. Application of computer-aided image interpretation to the diagnosos of periapical bone lesions. Dentomaxillofac Radiol, v.21, n.4, p.190-4, Nov. 1992.

46. NAVIA, J.M. Animal models in dental research. Birmingham, AL: University of Alabama Press, 1977.

47.NELVIG, P.; WING, K.; WELANDER, U. Sens-A-Ray. A new system for direct digital intraoral radiography. Oral Surg Oral Med Oral Pathol Oral Radiol Endod, v.74, n.6, p.818-23, Dec. 1992.

48. NOCITI Jr, F.H. et al. The influence of nicotine on the bone loss rate in ligature-induced periodontitis. A histometric study in rats. J Periodontol, v.71, n.9, p.1460-4, Sept. 2000.

49.NYMAN, S.; SCHROEDER, H.E.; LINDHE, J. Suppression of inflammation and bone resorption by indomethacin during experimental periodontitis in dogs. J Periodontol, v.50, n.9, p.450-61, Sept. 1979.

50.OHKI, M.; OKANO, T.; NAKAMURA, T. Factors determining the diagnostic accuracy of digitized conventional intraoral radiographs. Dentomaxillofac Radiol, v.23, n.2, p. 77-82, May 1994.

51. ØRSTAVIK, D. et al. Image analysis of endodontic radiographs: digital subtraction and quantitative densitometry. Endod Dent Traumatol, v.6, n.1, p.6-11, Feb. 1990.

52.ØRSTAVIK, D.; KEREKES, K.; ERIKSEN, H.M. The periapical index: a scoring system for radiographic assessment of apical periodontitis. Endod Dent Traumatol, v.2, n.1, p.20-34, Feb. 1986. 
53. ORTMAN, L.F.; McHENRY, K.; HAUSMANN, E. Relationship between alveolar bone measured by ${ }^{125} \mathrm{I}$ absorptiometry with analysis of standardized radiographs: 2. Bjorn technique. J Periodontol, v.53, n.5, p.311-4, May 1982.

54.PAPAPANOU, P.N.; WENNSTRÖM, J.L.; GRÖNDAHL, K. A 10-year retrospective study of periodontal disease progression. $\mathbf{J}$ Clin Periodontol, v.16, n.7, p.403-11, Aug. 1989.

55.ROVIN, S.; COSTISH, E.R.; GORDON, H.A. The influence of bacteria and irritation on the initiation of periodontal disease in germfree and conventional rats. J Periodontal Res, v.1, n.3, p.193-204, 1966.

56.RUTTIMANN, U.E.; WEBBER, R.L.; SCHMIDT, E. A robust digital method for film contrast correction in subtraction radiography. J Periodont Res, v.21, n.1, p.486-95, Sept. 1986.

57.SARMENTO, V.A. Proposta para diagnóstico radiográfico de alterações pulpares através da determinação do nível de cinza apical sobre imagens digitalizadas: estudo experimental em ratos. Porto Alegre, 2000. 283p. Tese (Doutorado). Faculdade de Odontologia, Pontifícia Universidade Católica do Rio Grande do Sul.

58.SARMENTO, V.A. et al. Avaliação da qualidade de obturação endodôntica através da digitalização direta de imagens. Rev Odonto Ciência, v.13, n.26, p.139-55, dez. 1998.

59.SARMENTO, V.A.; PRETTO, S.M.; COSTA, N.P. Entendendo a imagem digitalizada. Rev Odonto Ciência, v.14, n.27, p.171-8, jun. 1999. 
60.SARMENTO, V.A; RUBIRA, I.R.F. Mensuração da densidade óptica apical - uma proposta para diagnóstico diferencial em endodontia. J Bras Odont Clin, v.2, n.12, p.65-8, nov./dez. 1998.

61.SCHWARTZ, S.F.; FOSTER, J.K. Roentgenographic interpretation of experimentally produced bony lesions, 1. Oral Surg Oral Med Oral Pathol, v.32, n.4, p.606-12, Oct. 1971.

62.SHROUT, M.K. et al. Digital image analysis of cadaver mandibular trabecular bone patterns. J Periodontol, v.74, n.9, p.1342-7, Sept. 2003.

63.SHROUT, M.K.; HALL, J.M.; HILDEBOLT, C.E. Differentiation of periapical granulomas and radicular cysts by digital radiometric analysis. Oral Surg Oral Med Oral Pathol Oral Radiol Endod, v.76, n.3, p.356-61, Sept. 1993.

64.SOUTHARD, K.A. et al. The relationship between the density of the alveolar processes and that of post-cranial bone. J Dent Res, v.79, n.4, p.964-9, Apr. 2000.

65. SOUTHARD, T.E. et al. Geometric and densitometric standardization of intraoral radiography through use of a modified XCP system. Oral Surg Oral Med Oral Pathol Oral Radiol Endod, v.87, n.2, p.253-7, Feb. 1999.

66.STAMATAKIS, H.C.; WELANDER, U.; McDAVID, W.D. Physical properties of a photostimulable phosphor system for intra-oral radiography. Dentomaxillofac Radiol, v.29, n.1, p.28-34, Jan. 2000. 
67. VAN der STELT, P.F. Modern radiographic methods in the diagnosis of periodontal disease. Adv Dent Res, v.7, n.2, p.158-62, Aug. 1993.

68.VANDRE, R.H.; WEBBER, R.L. Future trends in dental radiology. Oral Surg Oral Med Oral Pathol Oral Radiol Endod, v.80, n.4, p.471-8, Oct. 1995.

69.VELDERS, X.L.; SANDERINK, G.C.H.; van der STELT, P.F. Dose reduction of two digital sensor systems measuring file lengths. Oral Surg Oral Med Oral Pathol Oral Radiol Endod, v.81, n.5, p.607-12, May 1996.

70.VERSTEEG, C.H.; SANDERINK, G.C.H.; VAN der STELT, P.F. Efficacy of digital intaoral radiography in clinical dentistry. J Dent, v.25, n.3-4, p.215-24, May/July 1997.

71.WARSHAWSKY, H.; MOORE, G. A technique for the fixation and decalcification of rat incisors for electron microscopy. J Histochem Cytochem., v.15, n.9, p.542-9, Sept. 1967.

72.WEINER, G.S.; DeMARCO,T.J.; BISSADA, N.F. Long term effect of systemic tetracycline administration on the severity of induced periodontitis in the rat. J Periodontol, v.50, n.12, p.619-23, Dec. 1979.

73.WENZEL, A. Sensor noise in direct digital imaging (the RadioVisioGraphic, Sens-A-Ray, and Visualix/Vixa systems) evaluated by subtraction radiography. Oral Surg Oral Med Oral Pathol Oral Radiol Endod, v.77, n.1, p.70-4, Jan. 1994.

74.WENZEL, A. Two decades of computerized information technologies in dental radiography. J Dent Res, v.81, n.9, p.590-3, Sept. 2002. 
75. WHITE, S.C. et al. Absence of radiometric differentiation between periapical cysts and granulomas. Oral Surg Oral Med Oral Pathol Oral Radiol Endod, v.78, n.5, p.650-4, Nov. 1994.

76. WHITE, S.C.; PHAROAH, M.J. Oral radiology: principles and interpretation. 5.ed. St Louis, Mosby, 2004.

77. WOLF,B et al. Reliability of assessing interproximal bone loss by digital radiography: intrabony defects. J Clin Periodontol, v.28, n.9, p.86978, Sept. 2001.

78.YOSHIURA, K.; OHKI, M.; YAMADA, N. Image analysis of microsialograms of the mouse parotid gland using image processing. Dentomaxillofac Radiol, v.20, n.1, p.17-24, Feb. 1991. 


\section{ABSTRACT \\ RADIOGRAPHIC EVALUATION OF PERIODONTAL BONE RESORPTION WITH PIXEL VALUE AND HISTOPATOLOGICAL ANALYSIS.}

The aim of this research was to evaluate the pixel value modification in periodontal disease sites using direct digital radiography and digitalized radiography. Periodontal disease was induced by a 3-0 silk ligature in the inferior right first molars of thirty Wistar rats. The inferior left first molar was the control. The animals were divided into groups: 1- seven days; 2- fourteen days and 3- twenty eight days. The mandibles were removed and radiographed with film size 2 and in a photoestimulable phosphor plate (Digora $\left.{ }^{\circledR}\right)$. Conventional radiographs were digitized in a laser scanner. The mandibles were processed and HE stained for histological analysis. The mean pixel values from the periodontal disease sites were measured by

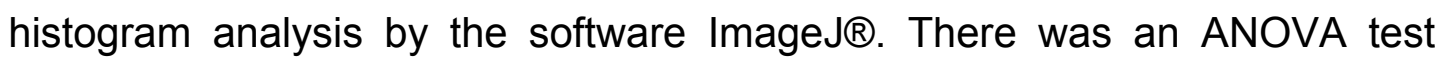
statistic significant difference among the pixel values for disease sites when compared to the control sites in the three groups for Digora ${ }^{\circledR}$ and digitized images. However, there was no significant difference for the disease sites regardind the pixel values among experimental periods. The longer the experimental period, more severe was the bone loss visualized histologically. In conclusion, pixel value analysis in a digital radiographic image may evidence bone loss when compared to the controls, but failed in detecting the progressive bone loss microscopically visualized. 